University of Nebraska - Lincoln

DigitalCommons@University of Nebraska - Lincoln

\title{
The Elasticity of Taxable Income over the 1980s and 1990s
}

Seth H. Giertz

University of Nebraska-Lincoln, sgiertz2@unl.edu

Follow this and additional works at: https://digitalcommons.unl.edu/econfacpub

Part of the Economics Commons

Giertz, Seth H., "The Elasticity of Taxable Income over the 1980s and 1990s" (2007). Economics Department Faculty Publications. 57.

https://digitalcommons.unl.edu/econfacpub/57

This Article is brought to you for free and open access by the Economics Department at DigitalCommons@University of Nebraska - Lincoln. It has been accepted for inclusion in Economics Department Faculty Publications by an authorized administrator of DigitalCommons@University of Nebraska - Lincoln. 


\title{
The Elasticity of Taxable Income over the 1980s and 1990s*
}

\begin{abstract}
Taxable (and broad) income elasticities are estimated using tax return data from 1979 to 2001. Data from the Continuous Work History Survey (CWHS) yield an estimated taxable income elasticity for the 1990s that is about half the corresponding 1980s estimate. Estimates from the full Statistics of Income, which heavily oversamples high-income filers, generally confirm the CWHS results. More sophisticated income control brings the estimates for the two decades closer together - to 0.40 for the 1980 s and 0.26 for the 1990 s. Work by Kopczuk (2005) implies that the narrowing of the tax base since 1986 could account for 14 to 29 percent of the remaining difference.
\end{abstract}

\section{INTRODUCTION}

$\mathrm{T}_{\mathrm{t} \text { tas }}^{\mathrm{b}}$ he degree to which taxes alter U.S. economic activity and tax-reporting behavior is a subject of debate. Estimates of the effect range from extremely large to almost none. For even modest changes to tax rates, the range of estimates implies differences in deadweight loss and income-tax revenue of many tens of billions of dollars. A key variable at the center of recent research is the elasticity of taxable income (ETI), which measures the responsiveness of reported taxable income to changes in marginal tax rates. ${ }^{1}$ The ETI, if accurately estimated, can be used to calculate both the change in deadweight $\operatorname{loss}^{2}$ and the change in income-tax revenue resulting from a change in tax rates. ${ }^{3}$ However, in practice, assessing

* Any views expressed are those of the author and should not be interpreted as those of the Congressional Budget Office.

1 Specifically, the ETI equals the percentage change in reported taxable income associated with a one-percent increase in the net-of-tax rate, where the net-of-tax rate equals one minus the marginal tax rate.

2 Feldstein (1999) shows that deadweight loss $=-0.5 \cdot(\text { TaxRate })^{2} \cdot(1-\text { TaxRate })^{-1}$ - ETI - TaxableIncome.

\section{Seth H. Giertz}

Tax Analysis Division, Congressional Budget Office, Washington, D.C. 20515

\section{National Tax Journal}

Vol. LX, No. 4

December 2007
3 The change in income tax revenue equals ETI $\cdot$ TaxableIncome $\cdot \Delta t \cdot(t / 1-t)$, where $t$ is the tax rate. This can be derived as follows:

$$
\begin{aligned}
\text { ETI } & =\text { Elasticity of Taxable Income }=\left(\frac{d \text { TaxRevenue }}{d(1-t)}\right) \cdot\left(\frac{1-t}{\text { TaxRevenue }}\right) \\
& \Rightarrow\left(\frac{d \text { TaxRevenue }}{d(1-t)}\right)=\text { ETI } \cdot\left(\frac{\text { TaxRevenue }}{1-t}\right)=\text { ETI } \cdot \text { TaxableIncome } \cdot\left(\frac{t}{1-t}\right) .
\end{aligned}
$$

Therefore, assuming a constant elasticity over the tax change, the change in revenues for a change in the tax rate $(\Delta t)$ can be expressed such that

$$
\Delta t \cdot\left(\frac{d \text { TaxRevenue }}{d(1-t)}\right)=\text { ETI } \cdot \text { TaxableIncome } \cdot \Delta t \cdot\left(\frac{t}{1-t}\right) \text {. }
$$


both the efficiency and revenue implications of tax-rate changes is more complex than the formulas suggest. For example, if the ETI differs by income, an accurate assessment of either efficiency or revenue implications requires a breakdown of the responses by income group. ${ }^{4}$

Despite a great deal of variation in ETI estimates, both across studies and within studies that explore different specifications, several recent papers have reported an overall ETI of about 0.40 . An often-cited study by Gruber and Saez (2002) examines responses to the tax cuts of 1981 and 1986, and finds an overall estimated ETI of 0.40 . However, Kopczuk (2005) finds similarly estimated results to be quite sensitive to sample selection and model specification. Both Giertz (2006) and Heim (2007) also report estimates for the 1990s that are very sensitive to an array of factors. Others (e.g., Saez (2004) and Goolsbee (1999)) report great heterogeneity in estimated responses across time periods.

The estimation portion of this paper first replicates Gruber and Saez's core results by applying their techniques to a dataset that is similar to the one that they used. My results for the 1980s closely parallel Gruber and Saez's results. Applying the same methodology to 1990s data and to data from both the 1980s and 1990s combined, however, yields estimated ETIs that are much smaller than corresponding estimates for the 1980s. In fact, using Gruber and Saez's preferred specification yields an estimated ETI for the 1990s that is a little more than half my corresponding estimate for the 1980s. Weighting regression results by income not only has an enormous impact on the estimates, but yields overall estimates that are driven by a tiny fraction of high-income filers. For example, excluding the 100 most influential observations (just 0.2 percent of the sample), as measured by a $d f b e t a$ test, lowers the estimated ETI for the 1980s from 0.37 to $0.08 .^{5}$

While the dfbeta tests suggest that the Continuous Work History Survey (CWHS) estimates may be imprecise because of the small number of very-high-income observations, estimates are generally very similar after adding data from primarily high-income tax filers to the sample. While the standard errors are much smaller and the estimates more robust with the larger dataset, the fact that estimates are often similar suggests that, despite the small number of very-high-income filers, the CWHS may be a viable dataset for examining behavioral responses to taxation.

The larger dataset also includes additional demographic information. This information (age, gender, and itemization status), using Gruber and Saez's preferred specification, has a positive, albeit modest, affect on the estimated ETI for the 1980s and a negligible affect on the 1990s estimate. When including this information, the larger dataset yields an ETI for the 1980 s and 1990s combined of 0.34 with a $\mathrm{t}$-value of over 7.5.

Even with the larger dataset, estimates for the 1980s and 1990s differ greatly. The model with demographics and Gruber and Saez's richest set of controls yields an estimated ETI for the 1980s of 0.43 and for the 1990s, $0.20 .^{6}$ Including separate

\footnotetext{
4 In addition, when external costs or benefits are present, assessing efficiency implications is also more complex. For example, suppose tax rates rise and, in response, taxable income falls, but a portion of that drop in taxable income comes from increased charitable contributions (and suppose those charities produce positive externalities). Or suppose that a tax increase is used to finance an underprovided public good. In such instances, the standard deadweight loss formula will overstate the efficiency cost of an increase in tax rates.

5 Excluding influential observations is not done to produce a "better" estimate, but rather to test whether a handful of observations may be driving the overall results. In fact, dropping observations in the manner described likely biases the estimates.

6 Restricting the sample to those with over $\$ 100,000$ in taxable income does not affect the ETI estimate for the 1980 s and raises the estimate for the 1990 s to 0.23 . However with the higher income cutoff, the estimated ETI for both decades combined rises by 30 percent, to 0.44 .
} 
and nonlinear controls for mean reversion and divergence within the income distribution narrows this difference, lowering the 1980s estimate to 0.40 and raising the 1990s estimate to 0.26 . Additionally, work by Kopczuk (2005) implies that changes to the tax base since 1986 (IRS, 1979-1998) could account for as much as 14 to 29 percent of this difference. However, this still leaves the vast majority of the difference in estimates between the two time periods unexplained.

When turning to a more encompassing income measure, broad income, substantial variation in estimated elasticities for the 1980s and 1990s is also observed. For the 1980s, the estimated broad income elasticity is 0.21 . For the 1980 s, the corresponding estimate is 0.13 . While the estimated broad income elasticity is much lower for the 1980s than the 1990s, the 1990s estimate represents a larger share of the corresponding taxable income elasticity estimate than does the 1980s estimate. Heterogeneous income elasticity estimates across tax changes is not a new finding. Saez (2004), using aggregated time-series data, finds great variation in income responses to tax changes over years 1960 to 2000. And Goolsbee (1999), using repeated cross-sections of data for selected years between 1920 and 1966, also finds substantial variation in estimated responses across tax changes.

\section{ISSUES IN THE ANALYSIS}

While taxes affect income growth, so do many other economic factors. Controlling for non-tax-induced trends in taxable income is a major obstacle to accurately estimating elasticities. The issue of nontax-related trends in income is given the most attention in this section because the approach used to control for those trends represents the most novel aspect of the model employed in this study-a model developed by Gruber and Saez (2002). The approach also takes into account other factors, such as mean reversion, tax-rate endogeneity, institutional changes (which often coincide with changes in the rate structure), and differences between transitory (or temporary) fluctuations and permanent (or longer-term) responses. (For a discussion of these issues and the related literature, see Giertz (2004) and Slemrod (1998).)

\section{Controlling for Exogenous Trends in Income}

The centerpiece of Gruber and Saez's approach is its controls for non-taxrelated heterogeneous shifts in income distribution and mean reversion. Over the past 30 years, the distribution of reported income has widened. In fact, that trend accelerated in the 1980s, especially at the top of the distribution. ${ }^{7}$ Because people with the highest income pay a disproportionate share of taxes-the top one percent pay approximately one-third of all federal income taxes-their behavior is especially important (see Internal Revenue Service (2004)). Not fully accounting for the portion of that income growth that is unrelated to tax policy can result in large biases. For example, the 1980s cuts in marginal tax rates were greatest at the top of the income distribution and, thus, inversely correlated with the great income growth at the top of the distribution. If the exogenous (non-tax-related) portion of that income growth is not fully accounted for, that trend will bias ETI estimates upward. Because this income

\footnotetext{
7 According to Piketty and Saez (2003), the share of income reported by the top ten percent of filers rose by more than a third, from 32.9 percent in 1979 to 41.4 percent in 1998; two-thirds of that increase went to the top one percent of taxpayers. The share of income reported by the top one-half of one percent more than doubled, the share reported by the top one-tenth of one percent nearly tripled, and the share reported by the top one-hundredth of one percent more than quadrupled.
} 
trend has been irregular, distributional changes in years without tax changes may not provide useful measures of exogenous shifts that occur during periods with tax changes.

Although changes to the income distribution are widely documented and theories such as heterogeneous (and diverging) returns to education and experience help explain the phenomenon, the underlying driving factors are not well understood, nor are the year-to-year deviations from that trend. ${ }^{8}$ The fact that the exogenous-income trend has persisted through periods of both increases and decreases in the level and progressivity of income tax rates suggests that it is, in large part, not a direct response to tax changes. Furthermore, Saez and Veall (2005) find an income trend at the top of the Canadian income distribution that closely parallels that in the U.S.-despite a different pattern of tax changes in Canada with much more modest reductions in marginal tax rates. That notwithstanding, the possibility that the phenomenon results from a longer-run and more-nuanced response to tax changes cannot entirely be ruled out. Note that the progressivity (especially within the top one percent of the income distribution $)^{9}$ of both the U.S. and Canadian tax systems has declined substantially since 1970 , as the concentration of income held by this group has risen substantially in both countries. By contrast, tax progressivity at the top of the French income distribution has remained stable (or possibly increased), while the income concentration at the top of the French income distribution too has remained relatively stable (Piketty and Saez, 2007).

\section{Controlling for Mean Reversion}

Mean reversion also complicates estimation. Over a person's lifetime, income often follows a general path, with many fluctuations. After income has been particularly high or low, it will often revert to a more normal path. That reversion is especially pronounced at the tails of the distribution. People at the high end of the income distribution are often not there for long, and will likely have a substantial drop in income that is unrelated to tax policy. At the other extreme, students will often have large increases in income when they enter the workforce. Estimating the ETI without fully controlling for mean reversion will erroneously count non-tax-related increases (by people below their lifetime path) and decreases (by those above their lifetime path) in taxable income as responses to changes in tax rates. Those factors bias ETI estimates in opposite directions, depending on whether tax rates are raised or lowered, but there is no reason to believe the biases will cancel each other out.

Research into the ETI is also complicated by the fact that the ETI appears to vary with income, rising as income increases. ${ }^{10}$ If so, a single overall elasticity will not be applicable when considering the impact of rate changes that target only part of the income distribution or that differ across the distribution. In addition, a meaningful average overall estimated ETI must take into account the correlation between income and the elasticities. The average response of all filers may be very different from an income-weighted estimate that reflects how taxable income (and to a lesser extent tax revenue) as a whole will respond.

8 For possible explanations driving the divergence at the top of the income distribution, see Lemieux (2006).

9 That is, within the top one percent of income, taxes as a share of income continue to increase with income; however, for 1970 the increase was very steep, whereas today it is modest.

10 People with higher incomes generally have more opportunities to respond to tax changes (see Saez (2004)). They generally itemize their tax returns, rely less on wage and salary income, and have more control over the timing and source of their income than do other groups. People with more modest incomes can alter their labor supply, but may have few other alternatives for altering their taxable income. 


\section{DATA AND METHODS}

This paper uses data on individual tax returns from the Statistics of Income (SOI) for years 1979 through 2001. The SOI is a stratified random sample of tax filers, compiled by the Internal Revenue Service, and includes all information reported on filers' tax returns, plus additional demographic information. In addition to the full SOI, the Continuous Work History Survey (CWHS), a confidential version of the data used by Gruber and Saez (2002), is used for the replication phase of the paper, as well as for some of the sensitivity analysis. The CWHS is a subset of filers from the SOI who are followed from year to year. Although the CWHS contains detailed and accurate information, it is deficient in two important respects. First, although the CWHS sample is quite large (for some years, more than 20,000), relatively few returns are from the very top of the income distribution. If high-income taxpayers dominate an estimate, that estimate using the CWHS will depend heavily on just a few filers. This shortcoming of the CWHS can be overcome by moving to the full SOI, which heavily over-samples high-income filers. Second, the CWHS (and the full SOI) includes only people who file returns and are listed as the primary filers. Thus, attrition is an issue.

While selection into the CWHS is designed to be random, selection into the full SOI is conditional on several factors, including income. More specifically, each individual is assigned a number at random, which does not change from year to year. For each year, tax returns are separated into strata based on AGI and the forms and schedules used by the filers. Sampling probabilities vary by strata and reach 100 percent for very-high-income filers. The returns in each stratum are sorted by the randomly assigned values and the strata sampling probability is used to determine the cut point for inclusion into the SOI. Because the individual maintains the same random value over time and because the stratum sampling probability simply determines the cut point for inclusion in the sample, once included in the SOI, an individual is automatically included in future years if his income remains the same or if his income increases because this would either put him in the same stratum or in a stratum with a higher sampling probability, thus maintaining or lowering the cut point for inclusion. Therefore, an individual observed in the base year is much more likely to be observed in the future year if his income rises than if it falls. In fact, the probability that one is observed in two different years is simply the minimum of the strata sampling probabilities for the two years. This raises the potential for spurious correlation between the dependent variable ( $\ln \left(\right.$ income $_{t} /$ income $\left._{t+1}\right)$ ) and the independent variables, including the tax variable. To avoid this possibility, (paired) observations from the full SOI are weighted by the reciprocal of their probability of appearing in the sample. ${ }^{11}$ This strategy is discussed in Imbens and Lancaster (1996) and in Auten and Carroll (1999), who employ this strategy using similar data. ${ }^{12}$

This paper follows Gruber and Saez (2002) in comparing behavior over threeyear intervals, using only people who filed tax returns in both the base (or initial) year and the third subsequent year. The overall SOI sample includes nearly 700,000 paired observations, with over 218,000 from the CWHS. For base years 1979 to 1998 , the CWHS sample includes just 113 returns with taxable income

11 For paired observation, the sampling probability is simply the minimum of the sampling probabilities for the two observations used in constructing the pair.

12 Additionally, income-weighted results for the full SOI are produced by simply multiplying all weights by income. 
greater than $\$ 1,000,000$, while the full SOI includes 113,673 such returns. ${ }^{13}$ (The CWHS includes just four filers with taxable income over $\$ 5,000,000$, while the full SOI includes 21,365.)

Income measures are defined according to 1990 law. Over time, both tax rates and the definition of taxable income itself change. Deductions are permitted in some years and not others. The definition of income can affect responses to changes in tax rates (Slemrod and Kopczuk, 2002). Furthermore, estimated responses of income to changes in tax rates may be spurious if the definition of income also changes between the two periods and a concurrent (as opposed to constant-law) definition of income is used (Slemrod, 1996). ${ }^{14}$ For the 1980 s and 1990 s, the Tax Reform Act of 1986 (TRA 86) presents the biggest obstacle to creating a constant law definition of income. Because deductions and exclusion were more generous pre TRA 86, it is easier to construct a constant law measure based on post-TRA-86 law. ${ }^{15}$ Imposing 1990 law on pre-TRA-86 returns generally results in larger taxable income measures than under pre-TRA-86 law. Additionally, it is assumed that these filers would have opted for the standard deduction (at the 1990 level, but adjusted for inflation) instead of their itemized deductions, if their itemized deductions based on 1990 law are less than the standard deduction. As with Gruber and Saez, income measures are adjusted by the growth in broad income, where broad income equals total income minus realized capital gains and Social Security benefits, using 1990 as the base. ${ }^{16}$ More specifically,

$$
\begin{aligned}
& \text { broad income = AGI - capital gains } \\
& \text { - supplemental (Schedule E) income } \\
& \text { or loss + dividends excluded from AGI } \\
& \text { + unemployment compensation not } \\
& \text { included in AGI + Keogh and traditional } \\
& \text { IRA contributions + forfeited interest } \\
& \text { penalties + alimony paid. }
\end{aligned}
$$

As with most studies in this literature, capital gains are excluded from the analysis because they are only observed when they are realized, and not when they accrue. Social Security benefits are excluded because they are not observed in all years. Schedule E income is excluded because it can change dramatically from the shifting of income between Subchapter $\mathrm{S}$ and Subchapter C corporations. Subchapter $\mathrm{S}$ income is reported on Schedule $\mathrm{E}$, whereas Subchapter $\mathrm{C}$ income is generally not observed at the individual level. ${ }^{17}$ (Additionally, Schedule E income was affected by changes to both depreciation rules and passive loss rules.) The other income measure, taxable income, equals broad income less the value of exemptions and the greater of the standard or itemized deductions. $^{18}$

13 This is based on incomes in 1992 dollars, as adjusted by rates of growth in broad income.

14 For example, before TRA 86, 40 percent of capital gains were included in taxable income. Post TRA 86, all capital gains were included. Thus, even if capital gains realizations remained unchanged by TRA 86, a concurrent income definition would show taxable income from capital gains rising by 150 percent.

15 Information on many of the sources of pre-TRA-86 deductions and exclusions are not reported after 1986. However, many of the post-TRA-86 deductions and exclusions were reported on (or can be imputed from) pre-reform returns.

16 The adjustment for broad-income growth is analogous to adjustments that transform nominal dollars into real dollars. Thus, for this paper, each individual's reported income is divided by the ratio of average broad income in 1990 over the average broad income in the year of the observation.

17 This issue is discussed in more detail later.

18 Eligible deductions from AGI include: moving expenses, IRA and Keogh payments, medical expenses exceeding 7.5 percent of AGI, state and local income taxes, real estate and property taxes, mortgage interest and payments for deductible points, charitable contributions, net casualty deduction, as well as other miscellaneous deductions. 
The sample includes only those with broad income greater than $\$ 10,000$ in the base year and positive income in the future year. Without those restrictions, the SOI sample is about 20 percent larger, and the CWHS sample is about 25 percent larger. Mean taxable base-year income, after adjusting by the growth rate in broad income, is $\$ 28,311$ for the CWHS sample and $\$ 26,961$ for the full SOI. For broad income, these numbers are $\$ 45,065$ and $\$ 43,581$, respectively (see Table 1$){ }^{19}$ In nominal dollars, mean taxable income ranges from $\$ 10,739$ in 1979 to $\$ 25,308$ in 1998 for the CWHS; the corresponding means for broad income range from $\$ 17,442$ to $\$ 43,289$. Individual marginal tax rates (both state and federal) are imputed using the Congressional Budget Office's internal tax calculators. ${ }^{20}$

The CWHS sample is very similar to data used by Gruber and Saez, but differs in several respects. First, Gruber and Saez use a publicly available version of the CWHS, which is slightly modified in order to protect the identity of taxpayers in the sample. Second, Gruber and Saez's sample ends in 1990, whereas my sample extends to 2001. Third, Gruber and Saez use the National Bureau of Economic Research's (NBER) TAXSIM model to impute their federal and state marginal tax rates, whereas I use the Congressional Budget Office's internal tax calculators.

Because Gruber and Saez did not use the full SOI, they did not need to employ the weighting strategy discussed above. They did weight their results by income, though. Weighting by income is intended to produce estimates reflective of the change in total reported taxable (or broad) income, which relates directly to the change in income-tax revenues. If responses were homogeneous throughout the reported income distribution, weighting would not affect the results. But, as a number of studies, including Gruber and Saez, have found, the ETI varies by income and is generally much larger for the highest-income filers. Weighting should produce estimates that are more indicative of overall responses, but, at the same time, the importance of weighting suggests that the model fit may be poor.

TABLE 1

SUMMARY STATISTICS: CWHS VERSUS SOI

\begin{tabular}{|c|c|c|}
\hline & CWHS & SOI \\
\hline Paired Observations ${ }^{\mathrm{a}}$ & 193,809 & 699,724 \\
\hline Paired Observations 1980s & 54,136 & 250,140 \\
\hline Paired Observations 1990s & 139,673 & 449,584 \\
\hline \multicolumn{3}{|c|}{ Returns with Base Year Taxable Income Greater than: } \\
\hline$\$ 1,000,000$ & 113 & 113,673 \\
\hline$\$ 5,000,000$ & 4 & 21,365 \\
\hline Mean Base Year Taxable Income ${ }^{b}$ & $\$ 28,311$ & $\$ 26,961$ \\
\hline Mean Baseyear Broad Income ${ }^{\mathrm{b}}$ & $\$ 45,065$ & $\$ 43,581$ \\
\hline Mean Federal Tax Rate & 21 & 21 \\
\hline Mean State Tax Rate & 4 & 4 \\
\hline Mean Net-of-Tax Rate & 75 & 75 \\
\hline Mean Federal Tax Liability ${ }^{\mathrm{b}}$ & 6,246 & 5,720 \\
\hline Mean State Tax Liability ${ }^{\mathrm{b}}$ & 1,361 & 1,241 \\
\hline
\end{tabular}

Notes: Estimates are based on Statistics of Income data from 1979 to 2001 . Filers with less than $\$ 10,000$ of broad income are excluded.

aSample sizes are for the taxable income regressions.

'Income and tax liabilities are expressed in 1992 dollars, as adjusted by the growth in broad income. Averages for the SOI are weighted to reflect the population of tax filers.

\footnotetext{
19 SOI averages are weighted to reflect a random sample. Without such weighting, the corresponding means are $\$ 641,978$ for taxable income and $\$ 818,212$ for broad income.

20 Jon Bakija designed the state tax calculator used by the Congressional Budget Office (see Bakija (2006)).
} 
The methodology follows directly from Gruber and Saez (2002). The income growth rate equals

$$
\begin{aligned}
& \ln \left(\frac{\text { income }_{t+3}}{\text { income }_{t}}\right)=\alpha_{t}+\xi \cdot \ln \left(\frac{1-\text { taxrate }_{t+3}}{1-\text { taxrate }_{t}}\right) \\
& \quad+\operatorname{mars} \cdot \beta_{1}+\text { spline }\left(\text { income }_{t}\right) \cdot \beta_{2} \\
& \quad+\operatorname{demog} \cdot \beta_{3}+\varepsilon_{t}{ }^{21}
\end{aligned}
$$

The dependent variable is log of income in the future year (income $_{t+3}$ ) divided by income in the base year (income $)_{t}$ ), where the future year is three years after the base. (The key independent variable equals the log of the net-of-tax rate in the future year divided by the net-of-tax rate in the base year.) To avoid endogeneity between the tax rate and income, a first stage regression is run to produce and exogenous measure of the log change in the net-of-tax rate. ${ }^{22}$ The coefficient on that variable, $\xi$, represents the ETI. Control variables include year-fixed effects, dummies for marital status (mars), and a ten-piece spline of the log of base-year income. The spline is intended to control for mean reversion and for non-taxrelated income trends that have differed across the reported income distribution in recent decades. Alternative specifications employed by Gruber and Saez and in this paper include a model with the $\log$ of base-year income in place of the spline and a specification that excludes the income control altogether. Additionally and following Kopczuk (2005), specifications that include separate controls for mean reversion and non-tax-related income trends are explored. This is done by including explanatory variables based on one-year lagged income and the difference between base-year income and the one-year lag as separate variables (and in place of the log of base-year income). (Gruber and Saez also include a variable to separate the income effect from the substitution effect. They conclude that the income effect is not important and, thus, exclude it from most of their analysis.) In addition to extending the years of data and adding more high-income filers, I also add a richer set of demographic information (demog), including age, gender, and itemization status.

\section{RESULTS}

This section begins by replicating Gruber and Saez's approach for the 1980s using the CWHS sample and then compares the two sets of results. Next, the same methodology is applied to the 1990s and to the full period, spanning 1979 to $2001 .{ }^{23}$ After a discussion of those results, the importance of income-weighting regressions is examined. Next, a dfbeta test is conducted and the sensitivity of the estimated ETIs to the exclusion of handfuls of the most influential observations is examined.

The CWHS analysis is followed by results for each of the periods from the full SOI. The full SOI is also used to examine the influence that several different factors have on the estimates. First, the affect of additional demographics is examined. Second, the model is altered to include

21 Note that, for simplicity, subscripts denoting the individual are omitted here.

22 The instrument is constructed by inflating base-year income by the growth in mean broad income over the three-year interval. Next, the tax calculator computes counterfactual tax rates based on the inflated income measure. Finally, two-stage least squares (2SLS) is employed, where, in the first stage, the log change in the actual net-of-tax rate is regressed against the counterfactual (or imputed) log change in the net-of-tax rate, along with the other independent variables.

23 Estimates for the 1980s tax changes use data from 1979 to 1990. Because each observation contains information from the base year and information on the same filer three years later, base years for the 1980s range from 1979 to 1987. Estimates for the 1990s tax changes use data from 1988 to 2001, with base years ranging from 1988 to 1998. 
separate controls for mean reversion and divergence within the income distribution. Third, the model is estimated for responses due to variation in federal tax rates and then again for variation in state tax rates. Finally, the ETI is re-estimated for a sample that includes only high-income filers. ${ }^{24}$

\section{Replicating Gruber and Saez}

Each pair of the six columns of Table 2 reports Gruber and Saez's estimated elasticities for the 1980s (for broad income and taxable income) under the following specifications: with no controls for exogenous income trends, with the log of base-year income as a control, and with a ten-piece spline of log income (Gruber and Saez's preferred specification). My comparable estimates for the same period are presented in Table 3. Despite using a slightly different data set and different marginal tax rate calculators, the two sets of results are quite similar. Estimated with no control for base-year income, the elasticities are negative, which is inconsistent with theoretical predictions. Adding the log of base-year income to the model results in an estimated ETI of just above 0.6 and a substantially smaller broad-income elasticity of 0.17 . Replacing the log of base-year income with the ten-piece spline yields an estimated ETI in the neighborhood of 0.4 and a corresponding estimated elasticity of broad income of $0.12 .{ }^{25}$ The fact that the estimated elasticities for broad income are so much lower than the corresponding ETI estimates suggests that a substantial portion of the taxable-income response may come via deductions and exemptions. Another contributing factor may be that the denominator for the broad-income calculation is larger, by definition; thus, for an identical dollar change, the estimated broad-income elasticity will be smaller than the corresponding ETI estimate. Smaller broad-income elasticities are consistent with Kopczuk's (2005) finding that income responses are a function of the tax base and that the greater is the availability of exemptions and deductions, the lower is the cost of responding to tax changes and, hence, the larger is the response.

\section{CWHS Results for the 1990s}

The same methodology generates estimated ETIs for the 1990s that are much smaller than those for the 1980s and not statistically significant, despite a sample size of nearly 140,000 (see Table 4). Gruber and Saez's preferred specification, which includes a ten-piece spline, yields an esti-

TABLE 2

INCOME-WEIGHTED ESTIMATES FOR THE 1980s (Gruber and Saez (2002) Results)

\begin{tabular}{|c|c|c|c|c|c|c|}
\hline \multirow[b]{2}{*}{ Income Controls: } & \multicolumn{2}{|c|}{ none } & \multicolumn{2}{|c|}{ log income } & \multicolumn{2}{|c|}{ 10-piece spline } \\
\hline & $\begin{array}{l}\text { Broad } \\
\text { Income }\end{array}$ & $\begin{array}{l}\text { Taxable } \\
\text { Income }\end{array}$ & $\begin{array}{l}\text { Broad } \\
\text { Income }\end{array}$ & $\begin{array}{l}\text { Taxable } \\
\text { Income }\end{array}$ & $\begin{array}{l}\text { Broad } \\
\text { Income }\end{array}$ & $\begin{array}{l}\text { Taxable } \\
\text { Income }\end{array}$ \\
\hline Elasticity & $\begin{array}{c}-0.30 \\
(0.120)\end{array}$ & $\begin{array}{c}-0.462 \\
(0.194)\end{array}$ & $\begin{array}{c}0.17 \\
(0.106)\end{array}$ & $\begin{array}{c}0.611 \\
(0.144)\end{array}$ & $\begin{array}{c}0.12 \\
(0.106)\end{array}$ & $\begin{array}{c}0.40 \\
(0.144)\end{array}$ \\
\hline Observations & 69,129 & 59,199 & 69,129 & 59,199 & 69,129 & 59,199 \\
\hline
\end{tabular}

Notes: This is a partial reproduction of Table 4 from Gruber and Saez (2002).

24 Estimates throughout this section are based on 2SLS, where, as discussed in the previous section, counterfactual net-of-tax rates are used as instruments for the actual rates-since the actual rate is endogenous. Throughout the analyses, instruments in the first-stage regressions show strong statistical significance (both as measured by $\mathrm{F}$ statistics and by $\mathrm{t}$ statistics for the estimated coefficients on the counterfactual tax variables).

25 As with Gruber and Saez, when including a ten-piece spline, broad income elasticities are never statistically different from zero (at the five percent level). 
TABLE 3

REPLICATED RESULTS FOR THE 1980s

\begin{tabular}{|c|c|c|c|c|c|c|}
\hline \multirow[b]{2}{*}{ Income Controls: } & \multicolumn{2}{|c|}{ none } & \multicolumn{2}{|c|}{ log income } & \multicolumn{2}{|c|}{ 10-piece spline } \\
\hline & $\begin{array}{l}\text { Broad } \\
\text { Income }\end{array}$ & $\begin{array}{l}\text { Taxable } \\
\text { Income }\end{array}$ & $\begin{array}{l}\text { Broad } \\
\text { Income }\end{array}$ & $\begin{array}{l}\text { Taxable } \\
\text { Income }\end{array}$ & $\begin{array}{c}\text { Broad } \\
\text { Income }\end{array}$ & $\begin{array}{l}\text { Taxable } \\
\text { Income }\end{array}$ \\
\hline Elasticity & $\begin{array}{l}-0.248 \\
(0.113)\end{array}$ & $\begin{array}{c}-0.369 \\
(0.111)\end{array}$ & $\begin{array}{c}0.166 \\
(0.113)\end{array}$ & $\begin{array}{c}0.625 \\
(0.146)\end{array}$ & $\begin{array}{c}0.124 \\
(0.110)\end{array}$ & $\begin{array}{c}0.373 \\
(0.160)\end{array}$ \\
\hline Married & $\begin{array}{c}0.003 \\
(0.012)\end{array}$ & $\begin{array}{r}-0.079 \\
(0.016)\end{array}$ & $\begin{array}{c}0.064 \\
(0.016)\end{array}$ & $\begin{array}{c}0.043 \\
(0.022)\end{array}$ & $\begin{array}{c}0.073 \\
(0.015)\end{array}$ & $\begin{array}{c}0.078 \\
(0.021)\end{array}$ \\
\hline Single & $\begin{array}{l}-0.016 \\
(0.013)\end{array}$ & $\begin{array}{l}-0.072 \\
(0.017)\end{array}$ & $\begin{array}{c}-0.014 \\
(0.014)\end{array}$ & $\begin{array}{c}-0.063 \\
(0.021)\end{array}$ & $\begin{array}{l}-0.014 \\
(0.014)\end{array}$ & $\begin{array}{c}-0.048 \\
(0.021)\end{array}$ \\
\hline $\ln ($ income $)$ & & & $\begin{array}{l}-0.100 \\
(0.018)\end{array}$ & $\begin{array}{l}-0.200 \\
(0.018)\end{array}$ & & \\
\hline Spline: decile 1 & & & & & $\begin{array}{c}0.000 \\
(0.000)\end{array}$ & $\begin{array}{c}-0.818 \\
(0.033)\end{array}$ \\
\hline decile 2 & & & & & $\begin{array}{l}-0.892 \\
(0.219)\end{array}$ & $\begin{array}{c}-0.567 \\
(0.040)\end{array}$ \\
\hline decile 3 & & & & & $\begin{array}{l}-0.205 \\
(0.052)\end{array}$ & $\begin{array}{c}-0.376 \\
(0.053)\end{array}$ \\
\hline decile 4 & & & & & $\begin{array}{l}-0.140 \\
(0.053)\end{array}$ & $\begin{array}{l}-0.409 \\
(0.063)\end{array}$ \\
\hline decile 5 & & & & & $\begin{array}{c}-0.217 \\
(0.059)\end{array}$ & $\begin{array}{c}-0.220 \\
(0.074)\end{array}$ \\
\hline decile 6 & & & & & $\begin{array}{c}-0.068 \\
(0.059)\end{array}$ & $\begin{array}{c}-0.224 \\
(0.083)\end{array}$ \\
\hline decile 7 & & & & & $\begin{array}{l}-0.122 \\
(0.063)\end{array}$ & $\begin{array}{l}-0.260 \\
(0.089)\end{array}$ \\
\hline decile 8 & & & & & $\begin{array}{c}-0.133 \\
(0.068)\end{array}$ & $\begin{array}{c}-0.218 \\
(0.079)\end{array}$ \\
\hline decile 9 & & & & & $\begin{array}{l}-0.019 \\
(0.100)\end{array}$ & $\begin{array}{c}-0.278 \\
(0.085)\end{array}$ \\
\hline decile 10 & & & & & $\begin{array}{c}-0.086 \\
(0.048)\end{array}$ & $\begin{array}{c}-0.074 \\
(0.039)\end{array}$ \\
\hline Constant & $\begin{array}{l}-0.091 \\
(0.014)\end{array}$ & $\begin{array}{c}0.008 \\
(0.018)\end{array}$ & $\begin{array}{c}0.940 \\
(0.187)\end{array}$ & $\begin{array}{c}1.982 \\
(0.180)\end{array}$ & $\begin{array}{c}0.657 \\
(0.139)\end{array}$ & $\begin{array}{c}7.422 \\
(0.257)\end{array}$ \\
\hline Observations & 60,092 & 54,136 & 60,092 & 54,136 & 60,092 & 54,136 \\
\hline
\end{tabular}

Notes: Estimates are based on Continuous Work History Survey data for 1979 to 1990. Estimates are from 2SLS regressions. The income range is $\$ 10,000$ and above. Regressions are weighted by income. All regressions include dummies for marital status and dummies for each base year. Robust standard errors (clustered by individual) are in parentheses.

mated ETI of 0.20 , or slightly more than half the size of my estimate for the 1980s. Replacing the log of base-year income with a spline has little impact on the estimated ETI for the 1990s, but reduces the estimate for the 1980s by more than 40 percent (from 0.63 to 0.37 ). Note that controlling for changes in income inequality may be more complex for the 1990s than for the 1980s, since top incomes, while trending upward, show much greater variation in the 1990s. 
TABLE 4

INCOME-WEIGHTED CWHS ESTIMATES FOR BOTH DECADES

\begin{tabular}{|c|c|c|c|c|c|c|}
\hline \multirow[b]{2}{*}{ Income Controls: } & \multicolumn{2}{|c|}{ none } & \multicolumn{2}{|c|}{ log income } & \multicolumn{2}{|c|}{ 10-piece spline } \\
\hline & $\begin{array}{l}\text { Broad } \\
\text { Income }\end{array}$ & $\begin{array}{l}\text { Taxable } \\
\text { Income }\end{array}$ & $\begin{array}{l}\text { Broad } \\
\text { Income }\end{array}$ & $\begin{array}{l}\text { Taxable } \\
\text { Income }\end{array}$ & $\begin{array}{c}\text { Broad } \\
\text { Income }\end{array}$ & $\begin{array}{l}\text { Taxable } \\
\text { Income }\end{array}$ \\
\hline Elasticity & $\begin{array}{c}0.475 \\
(0.105)\end{array}$ & $\begin{array}{c}0.738 \\
(0.168)\end{array}$ & $\begin{array}{c}0.184 \\
(0.094)\end{array}$ & $\begin{array}{c}0.177 \\
(0.137)\end{array}$ & $\begin{array}{c}0.148 \\
(0.097)\end{array}$ & $\begin{array}{c}0.195 \\
(0.144)\end{array}$ \\
\hline Married & $\begin{array}{l}-0.015 \\
(0.008)\end{array}$ & $\begin{array}{c}-0.122 \\
(0.014)\end{array}$ & $\begin{array}{c}0.087 \\
(0.011)\end{array}$ & $\begin{array}{c}0.063 \\
(0.017)\end{array}$ & $\begin{array}{c}0.08 \\
(0.009)\end{array}$ & $\begin{array}{c}0.086 \\
(0.015)\end{array}$ \\
\hline Single & $\begin{array}{l}-0.039 \\
(0.010)\end{array}$ & $\begin{array}{l}-0.090 \\
(0.016)\end{array}$ & $\begin{array}{l}-0.014 \\
(0.010)\end{array}$ & $\begin{array}{l}-0.042 \\
(0.017)\end{array}$ & $\begin{array}{l}-0.014 \\
(0.010)\end{array}$ & $\begin{array}{l}-0.027 \\
(0.017)\end{array}$ \\
\hline $\ln ($ income $)$ & & & $\begin{array}{l}-0.099 \\
(0.010)\end{array}$ & $\begin{array}{l}-0.162 \\
(0.013)\end{array}$ & & \\
\hline Spline: decile 1 & & & & & $\begin{array}{c}0.00 \\
(0.000)\end{array}$ & $\begin{array}{l}-0.827 \\
(0.021)\end{array}$ \\
\hline decile 2 & & & & & $\begin{array}{c}0.00 \\
(0.000)\end{array}$ & $\begin{array}{l}-0.504 \\
(0.024)\end{array}$ \\
\hline decile 3 & & & & & $\begin{array}{c}-0.243 \\
(0.045)\end{array}$ & $\begin{array}{l}-0.408 \\
(0.031)\end{array}$ \\
\hline decile 4 & & & & & $\begin{array}{l}-0.186 \\
(0.030)\end{array}$ & $\begin{array}{l}-0.293 \\
(0.039)\end{array}$ \\
\hline decile 5 & & & & & $\begin{array}{l}-0.109 \\
(0.030)\end{array}$ & $\begin{array}{c}-0.27 \\
(0.046)\end{array}$ \\
\hline decile 6 & & & & & $\begin{array}{l}-0.135 \\
(0.034)\end{array}$ & $\begin{array}{l}-0.277 \\
(0.046)\end{array}$ \\
\hline decile 7 & & & & & $\begin{array}{l}-0.039 \\
(0.035)\end{array}$ & $\begin{array}{l}-0.168 \\
(0.049)\end{array}$ \\
\hline decile 8 & & & & & $\begin{array}{c}-0.172 \\
(0.036)\end{array}$ & $\begin{array}{l}-0.232 \\
(0.057)\end{array}$ \\
\hline decile 9 & & & & & $\begin{array}{c}0.097 \\
(0.049)\end{array}$ & $\begin{array}{c}0.067 \\
(0.071)\end{array}$ \\
\hline decile 10 & & & & & $\begin{array}{l}-0.122 \\
(0.021)\end{array}$ & $\begin{array}{l}-0.155 \\
(0.028)\end{array}$ \\
\hline Constant & $\begin{array}{l}-0.067 \\
(0.011)\end{array}$ & $\begin{array}{l}-0.033 \\
(0.019)\end{array}$ & $\begin{array}{c}0.952 \\
(0.103)\end{array}$ & $\begin{array}{c}1.588 \\
(0.134)\end{array}$ & $\begin{array}{c}0.128 \\
(0.019)\end{array}$ & $\begin{array}{c}7.313 \\
(0.156)\end{array}$ \\
\hline Observations & 158,679 & 139,673 & 158,679 & 139,673 & 158,679 & 139,673 \\
\hline
\end{tabular}

Notes: Estimates are based on Continuous Work History Survey data for 1979 to 2001. Estimates are from 2SLS regressions. The income range is $\$ 10,000$ and above. Regressions are weighted by income. All regressions include dummies for marital status and dummies for each base year. Robust standard errors (clustered by individual) are in parentheses. 
TABLE 5

INCOME-WEIGHTED CWHS ESTIMATES FOR BOTH DECADES

\begin{tabular}{|c|c|c|c|c|c|c|}
\hline \multirow[b]{2}{*}{ Income Controls: } & \multicolumn{2}{|c|}{ none } & \multicolumn{2}{|c|}{ log income } & \multicolumn{2}{|c|}{ 10-piece spline } \\
\hline & $\begin{array}{l}\text { Broad } \\
\text { Income }\end{array}$ & $\begin{array}{l}\text { Taxable } \\
\text { Income }\end{array}$ & $\begin{array}{l}\text { Broad } \\
\text { Income }\end{array}$ & $\begin{array}{l}\text { Taxable } \\
\text { Income }\end{array}$ & $\begin{array}{l}\text { Broad } \\
\text { Income }\end{array}$ & $\begin{array}{l}\text { Taxable } \\
\text { Income }\end{array}$ \\
\hline Elasticity & $\begin{array}{c}0.121 \\
(0.077)\end{array}$ & $\begin{array}{c}0.192 \\
(0.103)\end{array}$ & $\begin{array}{c}0.174 \\
(0.078)\end{array}$ & $\begin{array}{c}0.305 \\
(0.099)\end{array}$ & $\begin{array}{c}0.149 \\
(0.080)\end{array}$ & $\begin{array}{c}0.298 \\
(0.100)\end{array}$ \\
\hline Married & $\begin{array}{c}-0.01 \\
(0.007)\end{array}$ & $\begin{array}{l}-0.113 \\
(0.011)\end{array}$ & $\begin{array}{c}0.082 \\
(0.010)\end{array}$ & $\begin{array}{c}0.056 \\
(0.015)\end{array}$ & $\begin{array}{c}0.079 \\
(0.008)\end{array}$ & $\begin{array}{c}0.085 \\
(0.013)\end{array}$ \\
\hline Single & $\begin{array}{l}-0.028 \\
(0.008)\end{array}$ & $\begin{array}{c}-0.083 \\
(0.012)\end{array}$ & $\begin{array}{l}-0.012 \\
(0.009)\end{array}$ & $\begin{array}{l}-0.047 \\
(0.014)\end{array}$ & $\begin{array}{l}-0.012 \\
(0.009)\end{array}$ & $\begin{array}{l}-0.032 \\
(0.014)\end{array}$ \\
\hline $\ln$ (income) & & & $\begin{array}{l}-0.099 \\
(0.009)\end{array}$ & $\begin{array}{l}-0.165 \\
(0.013)\end{array}$ & & \\
\hline Spline: decile 1 & & & & & $\begin{array}{c}0.00 \\
(0.000)\end{array}$ & $\begin{array}{l}-0.817 \\
(0.017)\end{array}$ \\
\hline decile 2 & & & & & $\begin{array}{c}0.00 \\
(0.000)\end{array}$ & $\begin{array}{c}-0.524 \\
(0.021)\end{array}$ \\
\hline decile 3 & & & & & $\begin{array}{l}-0.266 \\
(0.031)\end{array}$ & $\begin{array}{l}-0.385 \\
(0.027)\end{array}$ \\
\hline decile 4 & & & & & $\begin{array}{l}-0.167 \\
(0.025)\end{array}$ & $\begin{array}{l}-0.334 \\
(0.033)\end{array}$ \\
\hline decile 5 & & & & & $\begin{array}{l}-0.122 \\
(0.026)\end{array}$ & $\begin{array}{l}-0.265 \\
(0.039)\end{array}$ \\
\hline decile 6 & & & & & $\begin{array}{l}-0.131 \\
(0.028)\end{array}$ & $\begin{array}{c}-0.25 \\
(0.041)\end{array}$ \\
\hline decile 7 & & & & & $\begin{array}{l}-0.069 \\
(0.029)\end{array}$ & $\begin{array}{l}-0.196 \\
(0.043)\end{array}$ \\
\hline decile 8 & & & & & $\begin{array}{l}-0.151 \\
(0.032)\end{array}$ & $\begin{array}{l}-0.253 \\
(0.047)\end{array}$ \\
\hline decile 9 & & & & & $\begin{array}{c}0.074 \\
(0.048)\end{array}$ & $\begin{array}{c}0.01 \\
(0.065)\end{array}$ \\
\hline decile 10 & & & & & $\begin{array}{l}-0.116 \\
(0.020)\end{array}$ & $\begin{array}{c}-0.14 \\
(0.026)\end{array}$ \\
\hline Constant & $-(0.090)$ & $\begin{array}{c}(0.027) \\
0.015\end{array}$ & $\begin{array}{c}(0.917) \\
0.096\end{array}$ & $\begin{array}{c}(1.638) \\
0.129\end{array}$ & $\begin{array}{c}0.094 \\
(0.015)\end{array}$ & $\begin{array}{c}7.301 \\
(0.133)\end{array}$ \\
\hline Observations & 218,771 & 193,809 & 218,771 & 193,809 & 218,771 & 193,809 \\
\hline
\end{tabular}

Notes: Estimates are based on Continuous Work History Survey data for 1979 to 2001. Estimates are from 2SLS regressions. The income range is $\$ 10,000$ and above. Regressions are weighted by income. All regressions include dummies for marital status and dummies for each base year. Robust standard errors (clustered by individual) are in parentheses. 
Although the ETI estimates are much smaller for the 1990s than for the 1980s, the corresponding estimated broad-income elasticities are slightly larger (although still not statistically different from zero). Including the spline yields an estimated broad-income elasticity for the 1990s of about 0.15 , compared with 0.12 for the 1980s (see Table 3 and Table 4).

The ETI estimates for the different time periods suggest that mean reversion at the top of the income distribution (i.e., falling incomes) dominates the secular income trend (of rising top income shares) and that this may result in estimates that are biased in different directions depending on whether tax rates are raised or lowered. The likelihood or degree of this bias depends on the base-year income controls included in the regression. Without base-year income controls, estimates for the 1980s are much smaller-in fact, well below zero-than with controls, but, for the 1990s, the opposite is true: estimates without income controls are much larger than those with controls. Mean reversion at the top of the income distribution implies drops in income for the 1980s that are negatively correlated with the net-of-tax rate, which is rising. For the 1990s, similar drops in income are positively correlated with the net-of-tax rate, which is falling. People at the top of the income distribution have a relatively high probability of experiencing a substantial drop in income, but people with moderate incomes have only a small probability of experiencing tremendous income gains needed to push them to the top of the distribution.

\section{CWHS Results for the Full Sample Period}

Not surprisingly, the same techniques applied to the full CWHS sample (from 1979 to 2001) generally result in estimated ETIs that are smaller than those for the 1980s and larger than those for the 1990s. The specification with the ten-piece spline yields an estimated ETI of 0.30, or slightly higher than the average of the estimates for the 1980s and 1990s. The specification with the log of base-year income produces an estimated ETI of 0.31, which is higher than the 1990s estimate of 0.18 but is only half the corresponding 1980s estimate of 0.63 . Once again, estimated broad-income elasticities are stable: 0.15 with the spline and 0.17 (and statistically significant) with the log of income control.

\section{Weighting and Sensitivity to Sample Selection}

With many estimation techniques, a small number of outliers can exert a heavy influence on the estimated coefficients; in such case the estimates may not be indicative of the behavior of much of the sample. As a case in point, Slemrod (1996) finds evidence suggesting that just one taxpayer may have been responsible for a substantial portion of several of the estimates reported by Feldstein (1995). That possibility seems remote when regressions are unweighted and include well over 50,000 observations. With income-weighting, however, that is not necessarily the case. With incomeweighting, large numbers of taxpayers with lower reported incomes might exert much less influence on the overall results than might a few very-high-income filers. In fact, re-estimating Tables 4-6 without using income weights dramatically low-

TABLE 6

THE EFFECT OF EXCLUDING THE MOST INFLUENTIAL OBSERVATIONS OF INCOMEWEIGHTED ESTIMATES FOR THE $1980 \mathrm{~s}^{\mathrm{a}}$

\begin{tabular}{lcc}
\hline $\begin{array}{l}\text { Dropped } \\
\text { Observations }\end{array}$ & Sample Size & Estimated ETI \\
\hline 0 & 54,136 & 0.373 \\
10 & 54,126 & 0.235 \\
25 & 54,111 & 0.174 \\
50 & 54,086 & 0.116 \\
100 & 54,036 & 0.084 \\
\hline
\end{tabular}

Notes: Estimates are based on Continuous Work History Survey data for years 1979 to 1990.

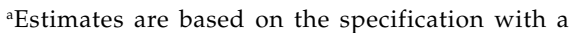
10-piece spline. Observations are dropped based on the size of their impact on the estimated ETI and as measured by a dfbeta test. 
ers the estimated ETIs for all time periods, suggesting that overall responsiveness is negligible. ${ }^{26}$ In order to further test the sensitivity of my estimates to very influential observations, I exclude as many as 100 observations that most affect the income-weighted estimates.

A dfbeta test for the 1980s sample measures the influence of each observation on the overall ETI estimate. For each observation, the dfbeta test calculates the difference between the estimated coefficient with and without that observation. Taxable-income elasticities for the 1980s are re-estimated based on the specification with the ten-piece spline and excluding the observations with the largest $d$ fbetas (in absolute value). Observations are excluded not to improve the ETI estimates, but rather to test the model's sensitivity to small numbers of observations. Dropping the ten most influential observations reduces the estimated ETI by more than 35 percent, to 0.24 . Dropping the 25 most influential observations further lowers the estimated ETI to 0.17, more than 50 percent below the initial estimate. Excluding the 100 most influential observations (0.2 percent of the sample) lowers the estimated ETI to $0.08,77$ percent lower than the initial estimate (see Table 6). Thus, despite the large sample size, income weighting results in estimates that are highly sensitive to just a few observations. For the most part, the most influential observations are taxpayers with very high taxable incomes who also report large changes in taxable income between the base year and the future year. Again note that dropping observations is likely biasing the estimates and that the purpose of this exercise is not to produce a better estimate, but to show that the overall estimates may be heavily dependent on a few observations. This result is not especially surprising because just a small slice of the CWHS sample is used to represent the segment of top income earners who are responsible for a very large share of overall income and tax revenues.

\section{Results from the Full SOI}

The analysis thus far calls into question the level of precision with which the CWHS-based taxable income responses are estimated. Despite a sample size of well over 50,000 for the 1980s, estimated ETIs are extremely sensitive to a tiny number of the most influential observations. Furthermore, despite a sample size of close to 140,000, estimated ETIs for the 1990s are far from statistically significant. Although sample sizes are quite large, the number of really high-income filers is very small. This, plus income-weighting the regressions, results in coefficients that are driven by a small number of observations. Additionally, for the 1990s a large fraction of the observations experience no change in tax rates because the 1990 and 1993 tax acts only changed tax rates for those in the upper tax brackets. Fortunately, this shortcoming of the CWHS can be overcome by turning to the full SOI, which, as discussed in the previous section, heavily over-samples high-income filers.

Given the sensitivity of the CWHS estimates, it is surprising that, for the most part, estimated ETIs from the full SOI are quite similar to the CWHS estimates. ${ }^{27}$ For the 1980s, the estimate ETI is 0.43 (versus 0.37 with the CWHS) with a t-value of over 5.2 (see Table 7). For the 1990s, the estimated ETI is 0.20 , almost exactly the same as the CWHS estimate, but with a $t-$ value of 3.3 (versus 1.35 with the CWHS) (see Table 8). For both decades combined, the estimated ETI is 0.34 (versus 0.30 with the CWHS) with a t-value of 7.5 (see Table 9).

26 However, including the log of base-year income, instead of a spline, results in estimated ETIs that are much larger and similar to those from the identically specified income-weighted model.

27 The full SOI estimates also include the richer set of demographic variables, but exclude state dummies. Including state dummies does very little to the estimates. 
TABLE 7

FULL SOI TAXABLE AND BROAD-INCOME ELASTICITIES FOR THE 1980s

\begin{tabular}{|c|c|c|c|c|c|c|}
\hline & \multicolumn{2}{|c|}{ No Income Controls } & \multicolumn{2}{|c|}{ Base-Year Income Controls } & \multicolumn{2}{|c|}{ Spline Income Controls } \\
\hline & $\begin{array}{l}\text { Broad } \\
\text { Income }\end{array}$ & $\begin{array}{l}\text { Taxable } \\
\text { Income }\end{array}$ & $\begin{array}{c}\text { Broad } \\
\text { Income }\end{array}$ & $\begin{array}{l}\text { Taxable } \\
\text { Income }\end{array}$ & $\begin{array}{c}\text { Broad } \\
\text { Income }\end{array}$ & $\begin{array}{l}\text { Taxable } \\
\text { Income }\end{array}$ \\
\hline$\overline{\ln \left(m t r_{t+3} / m t r_{t}\right)}$ & $\begin{array}{l}-0.033 \\
(0.036)\end{array}$ & $\begin{array}{c}-0.001 \\
(0.059)\end{array}$ & $\begin{array}{c}0.309 \\
(0.048)\end{array}$ & $\begin{array}{c}0.648 \\
(0.081)\end{array}$ & $\begin{array}{c}0.210 \\
(0.048)\end{array}$ & $\begin{array}{c}0.425 \\
(0.081)\end{array}$ \\
\hline Married & $\begin{array}{c}0.079 \\
(0.008)\end{array}$ & $\begin{array}{c}0.011 \\
(0.011)\end{array}$ & $\begin{array}{c}0.118 \\
(0.008)\end{array}$ & $\begin{array}{c}0.069 \\
(0.012)\end{array}$ & $\begin{array}{c}0.140 \\
(0.009)\end{array}$ & $\begin{array}{c}0.096 \\
(0.012)\end{array}$ \\
\hline Single & $\begin{array}{c}0.014 \\
(0.008)\end{array}$ & $\begin{array}{c}-0.012 \\
(0.012)\end{array}$ & $\begin{array}{c}0.023 \\
(0.008)\end{array}$ & $\begin{array}{c}0.007 \\
(0.012)\end{array}$ & $\begin{array}{c}0.031 \\
(0.008)\end{array}$ & $\begin{array}{c}0.028 \\
(0.012)\end{array}$ \\
\hline Age & $\begin{array}{c}0.045 \\
(0.003)\end{array}$ & $\begin{array}{c}0.072 \\
(0.004)\end{array}$ & $\begin{array}{c}0.056 \\
(0.004)\end{array}$ & $\begin{array}{c}0.086 \\
(0.005)\end{array}$ & $\begin{array}{c}0.065 \\
(0.004)\end{array}$ & $\begin{array}{c}0.10 \\
(0.005)\end{array}$ \\
\hline Age Squared/10 & $\begin{array}{c}-0.011 \\
(0.001)\end{array}$ & $\begin{array}{l}-0.017 \\
(0.001)\end{array}$ & $\begin{array}{l}-0.013 \\
(0.001)\end{array}$ & $\begin{array}{l}-0.019 \\
(0.001)\end{array}$ & $\begin{array}{l}-0.015 \\
(0.001)\end{array}$ & $\begin{array}{l}-0.022 \\
(0.001)\end{array}$ \\
\hline Age Cubed/100 & $\begin{array}{c}0.008 \\
(0.000)\end{array}$ & $\begin{array}{c}0.011 \\
(0.001)\end{array}$ & $\begin{array}{c}0.009 \\
(0.001)\end{array}$ & $\begin{array}{c}0.012 \\
(0.001)\end{array}$ & $\begin{array}{c}0.010 \\
(0.001)\end{array}$ & $\begin{array}{c}0.014 \\
(0.001)\end{array}$ \\
\hline $\operatorname{sex}$ & $\begin{array}{c}0.007 \\
(0.001)\end{array}$ & $\begin{array}{c}0.007 \\
(0.001)\end{array}$ & $\begin{array}{c}0.006 \\
(0.001)\end{array}$ & $\begin{array}{c}0.004 \\
(0.001)\end{array}$ & $\begin{array}{c}0.005 \\
(0.001)\end{array}$ & $\begin{array}{c}0.003 \\
(0.001)\end{array}$ \\
\hline itemzer_base & $\begin{array}{l}-0.004 \\
(0.004)\end{array}$ & $\begin{array}{l}-0.039 \\
(0.006)\end{array}$ & $\begin{array}{l}-0.055 \\
(0.005)\end{array}$ & $\begin{array}{c}-0.117 \\
(0.008)\end{array}$ & $\begin{array}{c}-0.069 \\
(0.005)\end{array}$ & $\begin{array}{l}-0.126 \\
(0.008)\end{array}$ \\
\hline $\ln ($ income $)$ & & & $\begin{array}{l}-0.091 \\
(0.005)\end{array}$ & $\begin{array}{l}-0.145 \\
(0.008)\end{array}$ & & \\
\hline decile 1 & & & & & $\begin{array}{l}-0.918 \\
(0.186)\end{array}$ & $\begin{array}{l}-0.610 \\
(0.016)\end{array}$ \\
\hline decile 2 & & & & & $\begin{array}{l}-0.219 \\
(0.017)\end{array}$ & $\begin{array}{l}-0.235 \\
(0.018)\end{array}$ \\
\hline decile 3 & & & & & $\begin{array}{l}-0.169 \\
(0.018)\end{array}$ & $\begin{array}{l}-0.213 \\
(0.025)\end{array}$ \\
\hline decile 4 & & & & & $\begin{array}{l}-0.123 \\
(0.022)\end{array}$ & $\begin{array}{l}-0.168 \\
(0.030)\end{array}$ \\
\hline decile 5 & & & & & $\begin{array}{l}-0.142 \\
(0.022)\end{array}$ & $\begin{array}{l}-0.176 \\
(0.033)\end{array}$ \\
\hline decile 6 & & & & & $\begin{array}{l}-0.041 \\
(0.027)\end{array}$ & $\begin{array}{l}-0.021 \\
(0.034)\end{array}$ \\
\hline decile 7 & & & & & $\begin{array}{l}-0.004 \\
(0.024)\end{array}$ & $\begin{array}{l}-0.069 \\
(0.031)\end{array}$ \\
\hline decile 8 & & & & & $\begin{array}{l}-0.033 \\
(0.041)\end{array}$ & $\begin{array}{c}0.006 \\
(0.054)\end{array}$ \\
\hline decile 9 & & & & & $\begin{array}{l}-0.066 \\
(0.054)\end{array}$ & $\begin{array}{l}-0.136 \\
(0.100)\end{array}$ \\
\hline decile 10 & & & & & $\begin{array}{l}-0.137 \\
(0.035)\end{array}$ & $\begin{array}{l}-0.131 \\
(0.069)\end{array}$ \\
\hline Constant & $\begin{array}{l}-0.73 \\
(0.054)\end{array}$ & $\begin{array}{l}-1.12 \\
(0.073)\end{array}$ & $\begin{array}{c}0.049 \\
(0.070)\end{array}$ & $\begin{array}{c}0.111 \\
(0.098)\end{array}$ & $\begin{array}{c}7.738 \\
(1.732)\end{array}$ & $\begin{array}{c}4.119 \\
(0.157)\end{array}$ \\
\hline Observations & 248,940 & 250,140 & 248,940 & 250,140 & 248,940 & 250,140 \\
\hline
\end{tabular}

Notes: Estimates are based on Statistics of Income data for years 1979 to 1990. Estimates are from 2SLS regressions. The income range is $\$ 10,000$ and above. Regressions are weighted by the inverse of sampling probabilities and by income (see the third section). Robust standard errors (clustered by individual) are in parentheses. 
TABLE 8

FULL SOI TAXABLE AND BROAD-INCOME ELASTICITIES FOR THE 1990s

\begin{tabular}{|c|c|c|c|c|c|c|}
\hline & No Inc & ontrols & Base-Yea & Controls & Spline In & Controls \\
\hline & $\begin{array}{l}\text { Broad } \\
\text { Income }\end{array}$ & $\begin{array}{l}\text { Taxable } \\
\text { Income }\end{array}$ & $\begin{array}{c}\text { Broad } \\
\text { Income }\end{array}$ & $\begin{array}{l}\text { Taxable } \\
\text { Income }\end{array}$ & $\begin{array}{l}\text { Broad } \\
\text { Income }\end{array}$ & $\begin{array}{l}\text { Taxable } \\
\text { Income }\end{array}$ \\
\hline $\ln \left(m t r_{t+3} / m t r_{t}\right)$ & $\begin{array}{c}0.478 \\
(0.044)\end{array}$ & $\begin{array}{c}0.745 \\
(0.071)\end{array}$ & $\begin{array}{c}0.133 \\
(0.038)\end{array}$ & $\begin{array}{c}0.144 \\
(0.058)\end{array}$ & $\begin{array}{c}0.125 \\
(0.037)\end{array}$ & $\begin{array}{c}0.198 \\
(0.060)\end{array}$ \\
\hline Married & $\begin{array}{c}0.091 \\
(0.010)\end{array}$ & $\begin{array}{c}0.013 \\
(0.011)\end{array}$ & $\begin{array}{c}0.139 \\
(0.009)\end{array}$ & $\begin{array}{c}0.082 \\
(0.010)\end{array}$ & $\begin{array}{c}0.137 \\
(0.010)\end{array}$ & $\begin{array}{c}0.092 \\
(0.011)\end{array}$ \\
\hline Single & $\begin{array}{c}0.017 \\
(0.009)\end{array}$ & $\begin{array}{l}-0.024 \\
(0.011)\end{array}$ & $\begin{array}{c}0.029 \\
(0.009)\end{array}$ & $\begin{array}{c}0.002 \\
(0.010)\end{array}$ & $\begin{array}{c}0.029 \\
(0.009)\end{array}$ & $\begin{array}{c}0.014 \\
(0.010)\end{array}$ \\
\hline Age & $\begin{array}{c}0.016 \\
(0.006)\end{array}$ & $\begin{array}{c}0.028 \\
(0.007)\end{array}$ & $\begin{array}{c}0.028 \\
(0.006)\end{array}$ & $\begin{array}{c}0.043 \\
(0.006)\end{array}$ & $\begin{array}{c}0.028 \\
(0.006)\end{array}$ & $\begin{array}{c}0.050 \\
(0.006)\end{array}$ \\
\hline Age Squared/10 & $\begin{array}{l}-0.006 \\
(0.001)\end{array}$ & $\begin{array}{l}-0.008 \\
(0.001)\end{array}$ & $\begin{array}{l}-0.007 \\
(0.001)\end{array}$ & $\begin{array}{l}-0.010 \\
(0.001)\end{array}$ & $\begin{array}{l}-0.007 \\
(0.001)\end{array}$ & $\begin{array}{c}-0.011 \\
(0.001)\end{array}$ \\
\hline Age Cubed/100 & $\begin{array}{c}0.004 \\
(0.001)\end{array}$ & $\begin{array}{c}0.006 \\
(0.001)\end{array}$ & $\begin{array}{c}0.005 \\
(0.001)\end{array}$ & $\begin{array}{c}0.006 \\
(0.001)\end{array}$ & $\begin{array}{c}0.005 \\
(0.001)\end{array}$ & $\begin{array}{c}0.007 \\
(0.001)\end{array}$ \\
\hline $\operatorname{sex}$ & $\begin{array}{c}0.004 \\
(0.001)\end{array}$ & $\begin{array}{c}0.002 \\
(0.001)\end{array}$ & $\begin{array}{c}0.001 \\
(0.001)\end{array}$ & $\begin{array}{l}-0.002 \\
(0.001)\end{array}$ & $\begin{array}{c}0.001 \\
(0.001)\end{array}$ & $\begin{array}{l}-0.001 \\
(0.001)\end{array}$ \\
\hline itemzer_base & $\begin{array}{c}0.012 \\
(0.005)\end{array}$ & $\begin{array}{l}-0.023 \\
(0.005)\end{array}$ & $\begin{array}{l}-0.096 \\
(0.006)\end{array}$ & $\begin{array}{l}-0.127 \\
(0.006)\end{array}$ & $\begin{array}{l}-0.083 \\
(0.006)\end{array}$ & $\begin{array}{l}-0.119 \\
(0.006)\end{array}$ \\
\hline $\ln ($ income $)$ & & & $\begin{array}{l}-0.107 \\
(0.004)\end{array}$ & $\begin{array}{l}-0.120 \\
(0.004)\end{array}$ & & \\
\hline decile 1 & & & & & $\begin{array}{l}-0.025 \\
(0.022)\end{array}$ & $\begin{array}{l}-0.554 \\
(0.014)\end{array}$ \\
\hline decile 2 & & & & & $\begin{array}{c}-0.19 \\
(0.021)\end{array}$ & $\begin{array}{l}-0.201 \\
(0.014)\end{array}$ \\
\hline decile 3 & & & & & $\begin{array}{l}-0.102 \\
(0.018)\end{array}$ & $\begin{array}{l}-0.170 \\
(0.017)\end{array}$ \\
\hline decile 4 & & & & & $\begin{array}{l}-0.153 \\
(0.020)\end{array}$ & $\begin{array}{c}-0.147 \\
(0.020)\end{array}$ \\
\hline decile 5 & & & & & $\begin{array}{l}-0.075 \\
(0.020)\end{array}$ & $\begin{array}{c}-0.021 \\
(0.016)\end{array}$ \\
\hline decile 6 & & & & & $\begin{array}{l}-0.033 \\
(0.013)\end{array}$ & $\begin{array}{l}-0.053 \\
(0.016)\end{array}$ \\
\hline decile 7 & & & & & $\begin{array}{l}-0.094 \\
(0.015)\end{array}$ & $\begin{array}{l}-0.097 \\
(0.022)\end{array}$ \\
\hline decile 8 & & & & & $\begin{array}{l}-0.139 \\
(0.026)\end{array}$ & $\begin{array}{c}-0.204 \\
(0.039)\end{array}$ \\
\hline decile 9 & & & & & $\begin{array}{l}-0.311 \\
(0.064)\end{array}$ & $\begin{array}{l}-0.314 \\
(0.079)\end{array}$ \\
\hline decile 10 & & & & & $\begin{array}{l}-0.095 \\
(0.046)\end{array}$ & $\begin{array}{c}-0.08 \\
(0.049)\end{array}$ \\
\hline Constant & $\begin{array}{l}-0.218 \\
(0.096)\end{array}$ & $\begin{array}{l}-0.304 \\
(0.104)\end{array}$ & $\begin{array}{c}0.776 \\
(0.100)\end{array}$ & $\begin{array}{c}0.720 \\
(0.103)\end{array}$ & $\begin{array}{c}0.080 \\
(0.100)\end{array}$ & $\begin{array}{c}4.472 \\
(0.150)\end{array}$ \\
\hline Observations & 323,776 & 449,584 & 323,776 & 449,584 & 323,776 & 449,584 \\
\hline
\end{tabular}

Notes: Estimates are based on Statistics of Income data for years 1988 to 2001. Estimates are from 2SLS regressions. The income range is $\$ 10,000$ and above. Regressions are weighted by the inverse of sampling probabilities and by income (see the third section). Robust standard errors (clustered by individual) are in parentheses. 
TABLE 9

FULL SOI TAXABLE AND BROAD-INCOME ELASTICITIES FOR THE 1980s AND 1990s

\begin{tabular}{|c|c|c|c|c|c|c|}
\hline & \multicolumn{2}{|c|}{ No Income Controls } & \multicolumn{2}{|c|}{ Base-Year Income Controls } & \multicolumn{2}{|c|}{ Spline Income Controls } \\
\hline & $\begin{array}{l}\text { Broad } \\
\text { Income }\end{array}$ & $\begin{array}{l}\text { Taxable } \\
\text { Income }\end{array}$ & $\begin{array}{l}\text { Broad } \\
\text { Income }\end{array}$ & $\begin{array}{l}\text { Taxable } \\
\text { Income }\end{array}$ & $\begin{array}{c}\text { Broad } \\
\text { Income }\end{array}$ & $\begin{array}{l}\text { Taxable } \\
\text { Income }\end{array}$ \\
\hline$\overline{\ln \left(m t r_{t+3} / m t r_{t}\right)}$ & $\begin{array}{c}0.168 \\
(0.028)\end{array}$ & $\begin{array}{c}0.277 \\
(0.045)\end{array}$ & $\begin{array}{c}0.247 \\
(0.027)\end{array}$ & $\begin{array}{c}0.359 \\
(0.044)\end{array}$ & $\begin{array}{c}0.227 \\
(0.028)\end{array}$ & $\begin{array}{c}0.339 \\
(0.045)\end{array}$ \\
\hline Married & $\begin{array}{c}0.081 \\
(0.006)\end{array}$ & $\begin{array}{c}0.01 \\
(0.008)\end{array}$ & $\begin{array}{c}0.131 \\
(0.007)\end{array}$ & $\begin{array}{c}0.074 \\
(0.008)\end{array}$ & $\begin{array}{c}0.141 \\
(0.007)\end{array}$ & $\begin{array}{c}0.093 \\
(0.008)\end{array}$ \\
\hline Single & $\begin{array}{c}0.012 \\
(0.006)\end{array}$ & $\begin{array}{l}-0.019 \\
(0.008)\end{array}$ & $\begin{array}{c}0.029 \\
(0.006)\end{array}$ & $\begin{array}{c}0.002 \\
(0.008)\end{array}$ & $\begin{array}{c}0.034 \\
(0.006)\end{array}$ & $\begin{array}{c}0.017 \\
(0.008)\end{array}$ \\
\hline Age & $\begin{array}{c}0.031 \\
(0.004)\end{array}$ & $\begin{array}{c}0.046 \\
(0.005)\end{array}$ & $\begin{array}{c}0.041 \\
(0.003)\end{array}$ & $\begin{array}{c}0.057 \\
(0.004)\end{array}$ & $\begin{array}{c}0.045 \\
(0.004)\end{array}$ & $\begin{array}{c}0.068 \\
(0.004)\end{array}$ \\
\hline Age Squared/10 & $\begin{array}{l}-0.009 \\
(0.001)\end{array}$ & $\begin{array}{l}-0.012 \\
(0.001)\end{array}$ & $\begin{array}{c}-0.01 \\
(0.001)\end{array}$ & $\begin{array}{l}-0.013 \\
(0.001)\end{array}$ & $\begin{array}{l}-0.011 \\
(0.001)\end{array}$ & $\begin{array}{l}-0.015 \\
(0.001)\end{array}$ \\
\hline Age Cubed/100 & $\begin{array}{c}0.006 \\
(0.001)\end{array}$ & $\begin{array}{c}0.008 \\
(0.001)\end{array}$ & $\begin{array}{c}0.007 \\
(0.001)\end{array}$ & $\begin{array}{c}0.008 \\
(0.001)\end{array}$ & $\begin{array}{c}0.007 \\
(0.001)\end{array}$ & $\begin{array}{c}0.009 \\
(0.001)\end{array}$ \\
\hline $\operatorname{sex}$ & $\begin{array}{c}0.006 \\
(0.001)\end{array}$ & $\begin{array}{c}0.004 \\
(0.001)\end{array}$ & $\begin{array}{c}0.003 \\
(0.001)\end{array}$ & $\begin{array}{c}0.001 \\
(0.001)\end{array}$ & $\begin{array}{c}0.003 \\
(0.001)\end{array}$ & $\begin{array}{c}0.000 \\
(0.001)\end{array}$ \\
\hline itemzer_base & $\begin{array}{c}0.009 \\
(0.003)\end{array}$ & $\begin{array}{l}-0.024 \\
(0.004)\end{array}$ & $\begin{array}{l}-0.076 \\
(0.004)\end{array}$ & $\begin{array}{l}-0.123 \\
(0.005)\end{array}$ & $\begin{array}{l}-0.079 \\
(0.004)\end{array}$ & $\begin{array}{l}-0.125 \\
(0.005)\end{array}$ \\
\hline $\ln ($ income $)$ & & & $\begin{array}{c}-0.098 \\
(0.003)\end{array}$ & $\begin{array}{l}-0.121 \\
(0.003)\end{array}$ & & \\
\hline decile 1 & & & & & $\begin{array}{l}-0.033 \\
(0.122)\end{array}$ & $\begin{array}{l}-0.573 \\
(0.011)\end{array}$ \\
\hline decile 2 & & & & & $\begin{array}{l}-0.203 \\
(0.013)\end{array}$ & $\begin{array}{l}-0.218 \\
(0.011)\end{array}$ \\
\hline decile 3 & & & & & $\begin{array}{l}-0.154 \\
(0.012)\end{array}$ & $\begin{array}{l}-0.182 \\
(0.014)\end{array}$ \\
\hline decile 4 & & & & & $\begin{array}{l}-0.125 \\
(0.014)\end{array}$ & $\begin{array}{l}-0.175 \\
(0.017)\end{array}$ \\
\hline decile 5 & & & & & $\begin{array}{l}-0.133 \\
(0.014)\end{array}$ & $\begin{array}{l}-0.062 \\
(0.015)\end{array}$ \\
\hline decile 6 & & & & & $\begin{array}{l}-0.016 \\
(0.013)\end{array}$ & $\begin{array}{l}-0.031 \\
(0.015)\end{array}$ \\
\hline decile 7 & & & & & $\begin{array}{l}-0.062 \\
(0.013)\end{array}$ & $\begin{array}{l}-0.065 \\
(0.018)\end{array}$ \\
\hline decile 8 & & & & & $\begin{array}{l}-0.101 \\
(0.021)\end{array}$ & $\begin{array}{l}-0.143 \\
(0.030)\end{array}$ \\
\hline decile 9 & & & & & $\begin{array}{l}-0.267 \\
(0.047)\end{array}$ & $\begin{array}{l}-0.296 \\
(0.058)\end{array}$ \\
\hline decile 10 & & & & & $\begin{array}{l}-0.130 \\
(0.038)\end{array}$ & $\begin{array}{l}-0.120 \\
(0.037)\end{array}$ \\
\hline Constant & $\begin{array}{l}-0.529 \\
(0.056)\end{array}$ & $\begin{array}{c}-0.749 \\
(0.070)\end{array}$ & $\begin{array}{c}0.363 \\
(0.062)\end{array}$ & $\begin{array}{c}0.343 \\
(0.075)\end{array}$ & $\begin{array}{c}-0.217 \\
(0.112)\end{array}$ & $\begin{array}{c}4.249 \\
(0.114)\end{array}$ \\
\hline Observations & 572,716 & 699,724 & 572,716 & 699,724 & 572,716 & 699,724 \\
\hline
\end{tabular}

Notes: Estimates are based on Statistics of Income data for years 1979 to 2001. Estimates are from 2SLS regressions. The income range is $\$ 10,000$ and above. Regressions are weighted by the inverse of sampling probabilities and by income (see the third section). Robust standard errors (clustered by individual) are in parentheses. 
For broad income, the SOI-based elasticity estimate for the 1980s is much larger than the estimate from the CWHS (0.21 versus 0.12 ). For the $1990 \mathrm{~s}$, the estimates are much closer ( 0.13 with the full SOI and 0.15 with the CWHS). For both decades combined, the estimated broad-income elasticity is 0.23 (versus 0.15 with the CWHS), but still smaller than the corresponding ETI estimate. While the estimates (for broad income) from the CWHS are never statistically significant at the five-percent level, the SOI-based estimates are all statistically significant at well above the one percent level.

\section{Adding Demographics to the Model}

Recall that the analysis based on the CWHS sample excluded all demographic variables except marital status. When turning to the full SOI, potentially important variables such as gender, age (as well as age squared and age cubed) and itemization status are added to the model. ${ }^{28} \mathrm{As}$ Table 10 shows, including demographics results in larger estimated elasticities (when using the model that includes a ten-piece spline) for the 1980s. The effect on the estimated elasticities for the 1990s is mixed; here the estimated broad-income elasticity falls, while the corresponding measure for taxable income remains essentially unchanged.

For the 1980s additional demographic variables raise the estimated ETI from 0.37 to 0.43 and the corresponding estimated elasticity for broad income from 0.18 to 0.21 . For the 1990s, however, the added variables have almost no effect on the estimated ETI. For broad income, the corresponding estimated elasticity falls from 0.17 to 0.13 . For the full period, the pattern of the 1980s tends to dominate. Additional demographics raise the estimated ETI, for the full period, from 0.28 to 0.34 , and the estimated broad-income elasticity from 0.20 to 0.23 .

In most cases, the added demographics show strong statistical significance (see Table 7, Table 8, and Table 9). Age, included as a third-order polynomial, shows strong statistical significance (as measured by F-tests) for both time periods for both broad and taxable income. Itemizer status is negative and strongly significant. The effect of (the primary filer's) gender, on the other hand, is close to zero and not statistically significant. The effect of demographics on the estimates implies that those new variables are somewhat correlated with unobserved

TABLE 10

INCLUSION OF ADDITIONAL DEMOGRAPHIC VARIABLES

\begin{tabular}{|c|c|c|c|c|}
\hline & \multicolumn{2}{|c|}{ Broad Income } & \multicolumn{2}{|c|}{ Taxable Income } \\
\hline & (1) & (2) & (3) & (4) \\
\hline $\begin{array}{l}\text { Added Demographics } \\
1979 \text { to } 1987\end{array}$ & $\begin{array}{c}\text { No } \\
0.183 \\
(0.052)\end{array}$ & $\begin{array}{c}\text { Yes } \\
0.210 \\
(0.048)\end{array}$ & $\begin{array}{c}\text { No } \\
0.365 \\
(0.083)\end{array}$ & $\begin{array}{c}\text { Yes } \\
0.425 \\
(0.081)\end{array}$ \\
\hline 1988 to 1998 & $\begin{array}{c}0.174 \\
(0.038)\end{array}$ & $\begin{array}{c}0.125 \\
(0.037)\end{array}$ & $\begin{array}{c}0.192 \\
(0.060)\end{array}$ & $\begin{array}{c}0.198 \\
(0.060)\end{array}$ \\
\hline 1979 to 1998 & $\begin{array}{c}0.198 \\
(0.029)\end{array}$ & $\begin{array}{c}0.227 \\
(0.028)\end{array}$ & $\begin{array}{c}0.276 \\
(0.046)\end{array}$ & $\begin{array}{c}0.339 \\
(0.045)\end{array}$ \\
\hline
\end{tabular}

Notes: Estimates are based on Statistics of Income data. Estimates are from 2SLS regressions. The income range is $\$ 10,000$ and above. Regressions are weighted by the inverse of sampling probabilities and by income (see the third section). Robust standard errors (clustered by individual) are in parentheses.

28 Itemization status is included in order to help capture non-tax-related income patterns that are correlated with itemizing. The drawback here is that the decision to itemize could be endogenous, and responsive to changes in tax rates. In any event, excluding itemization status from the added demographic variable has almost no effect on estimated elasticities for any of the specifications or time periods. 
(and non-tax-related) factors that determine income changes and, thus, may help isolate the tax-related portion of changes in income. ${ }^{29}$

\section{Separate Controls for Mean Reversion and Divergence in the Income Distribution}

Kopczuk (2005) makes a compelling argument that mean reversion and non-tax-related divergence in the income distribution are two separate phenomena and that it is unlikely that one variable will capture both effects. To address this, Kopczuk includes separate variables to control for each of the two different phenomena. To account for mean reversion, Kopczuk includes a function of income in the year preceding the base year. To control for divergence in the income distribution, he includes a function of the difference between current (or base-year) income and income in the preceding year.

To examine the implications of using one variable to control for both income divergence and mean reversion, I explore two specifications employed by Kopczuk and find that using his strongest set of controls has a modest and negative effect on the estimated ETI for the 1980s, but a larger and positive effect on the esti- mate for the 1990s. In one specification, I include both of the control variables (lagged income and the change in income from the previous to the current year) in $\log$ form; in the other, I include the same variables as ten-piece splines. When including the two variables in log form, the biggest change is observed for the 1980s, where the estimated ETI rises by almost 0.05 (when compared to results from the model that includes the log of base-year income) (see Table 11). When including the two logged variables as ten-piece splines, in place of a ten-piece spline of log income, the estimated ETI falls from 0.43 to 0.40 , when compared to the corresponding estimate for the 1980s, and for the full period, the estimate is virtually unchanged. For the 1990s the impact is greater, raising the estimate from 0.20 to 0.26 .

\section{Separately Estimated Responses for State and Federal Tax Rates}

The inclusion of state tax rates in the marginal rate calculation adds a source of cross-sectional variation across individuals who may be very similar in other respects (such as income). Including this cross-sectional variation may be important in identifying taxable income

TABLE 11

SEPARATE CONTROLS FOR MEAN REVERSION AND DIVERGENCE IN THE INCOME DISTRIBUTION

\begin{tabular}{|c|c|c|c|}
\hline Income Controls & $\begin{array}{c}1980 \text { to } \\
1987\end{array}$ & $\begin{array}{c}1988 \text { to } \\
1998\end{array}$ & $\begin{array}{c}1980 \text { to } \\
1998\end{array}$ \\
\hline$\overline{l n}\left(\right.$ taxable income $\left._{t-1}\right)$ and ln(taxable income t taxable income $\left._{t-1}\right)$ & $\begin{array}{c}0.666 \\
(0.116)\end{array}$ & $\begin{array}{c}0.191 \\
(0.059)\end{array}$ & $\begin{array}{c}0.334 \\
(0.053)\end{array}$ \\
\hline Spline of $\ln \left(\right.$ taxable income $\left._{t-1}\right)$ and spline of $\ln \left(\right.$ taxable income, $/$ taxable income $\left.{ }_{t-1}\right)$ & $\begin{array}{c}0.400 \\
(0.108)\end{array}$ & $\begin{array}{c}0.264 \\
(0.060)\end{array}$ & $\begin{array}{c}0.345 \\
(0.056)\end{array}$ \\
\hline Observations & 148,837 & 350,030 & 498,867 \\
\hline
\end{tabular}

Notes: Estimates are based on Statistics of Income data. Estimates are from 2SLS regressions. The income range is $\$ 10,000$ and above. Regressions are weighted by the inverse of sampling probabilities and by income (see the third section). Robust standard errors (clustered by individual) are in parentheses.

29 Dropping filers with base-year ages greater than 60 and excluding the age variables results in estimates that are almost the same as the core results, which include full demographics and impose no age restrictions. This suggests that retirement patterns, which are often associated with large drops in income, were likely not biasing earlier estimates from datasets that did not include age. 
responses because exogenous income trends, which are known to fluctuate from year to year and to vary greatly across the taxable income distribution, pose problems for other identification strategies. Furthermore, excluding changes to state rates would likely bias the net-of-tax rate variable, thus contaminating the ETI estimates.

A caveat to including state rates is that, to some degree, state tax rates are likely endogenous because some people base their decision to live in a particular state, at least partially, on its tax system. ${ }^{30}$ Feldstein and Wrobel (1998) contend that states are limited in their ability to redistribute income. A move toward a more progressive state tax system, it is argued, will be met by out-migration of high-paying jobs. For this state, pre-tax wages would rise (and employment would fall) in the high-skilled sector, resulting in the same level of after-tax income inequality. ${ }^{31}$ The endogeneity of state rates is not necessarily an issue when state rates increase uniformly across the income distribution, and these increased revenues are used to provide services whose benefits are also widespread. It is much more likely to be relevant when states alter the progressivity of their tax system, or alter their rates uniformly without commensurate changes to government services. ${ }^{32}$ In sum, migration in response to state tax changes is in itself a behavioral response to taxation, but one that complicates the ETI estimation process. ${ }^{33}$
While it is not known how great the role of interstate migration and wage capitalization is when analyzing changes to state tax rates, it is possible to estimate elasticities for models that exclude variation resulting from federal rates, and for models that exclude variation resulting from state tax rates. Simply excluding one component of the overall marginal rate will likely add little insight because doing so presumes that one component of the overall marginal rate is responsible for the entire tax effect. Thus, the log change in the overall tax rate is still used as the key dependent variable, but in one specification the predicted log change in the state rate is used as an instrument (instead of the corresponding change resulting from changes to both federal and state law) and in the other the predicted log change for only the federal rate is used as an instrument. Therefore, on average the key dependent variable will be the same as before, but the variation in this variable will now be based on only one of the two components of the overall marginal tax rate.

The model that includes a ten-piece spline and uses just the federal rate as an instrument yields estimates that are very similar to those from the corresponding model that includes variation from the combination of federal and state tax rates. This is true for both broad and taxable income (see Panel 1 of Table 12).

Including only variation from state net-of-tax rates yields ETI estimates that are somewhat smaller than when both

30 As anecdotal evidence of that possibility, a number of high-paid celebrities have moved their primary residences from high-tax states, such as California, to low-tax states, such as Florida, Texas, and Nevada, which do not have state income taxes. The phenomenon is sometimes referred to as the "Tiger Woods Effect" (Jones, 2003). Woods, who grew up in California and attended Stanford University, moved his primary residence from California to Florida shortly after turning professional. Woods recently remarked, "We're definitely residing in Florida and I don't see why we should leave-especially with zero income tax" (Harig, 2004).

31 Analogously, transfers to low-income workers will lead to an inflow of low-skilled workers, pushing down their pre-transfer income.

32 For example, if a state enacts a proportional increase in its tax burden, that does not result in greater or improved government services.

33 It is likely that migration is motivated by average tax rates, controlling for the level of government services, as opposed to marginal rates, which drive behavioral responses to federal rate changes (or in situations where migration is prohibitively expensive). 
TABLE 12

COMPARISON OF ESTIMATES USING FEDERAL AND STATE MARGINAL TAX RATES

\begin{tabular}{lccccccc}
\hline & \multicolumn{3}{c}{ Panel 1: Federal Rates Only } & & \multicolumn{3}{c}{ Panel 2: State Rates Only } \\
\cline { 2 - 3 } & 1979 to 1987 & 1988 to 1998 & 1979 to 1998 & & 1979 to 1987 & 1988 to 1998 & 1979 to 1998 \\
\hline Taxable Income & 0.423 & 0.212 & 0.347 & & 0.343 & 0.105 & 0.226 \\
& $(0.061)$ & $(0.060)$ & $(0.038)$ & & $(0.098)$ & $(0.103)$ & $(0.066)$ \\
Broad Income & 0.205 & 0.11 & 0.192 & & 0.365 & 0.081 & 0.215 \\
& $(0.046)$ & $(0.037)$ & $(0.026)$ & & $(0.070)$ & $(0.059)$ & $(0.041)$ \\
\hline
\end{tabular}

Notes: Estimates are based on Statistics of Income data. Estimates are from 2SLS regressions and include a $10-$ Piece Spline of $\ln ($ Income). The income range is $\$ 10,000$ and above. Regressions are weighted by the inverse of sampling probabilities and by income (see the third section). Robust standard errors (clustered by individual) are in parentheses. Coefficients other than the elasticities are suppressed.

federal and state or only federal rate changes are included (see Panel 2 of Table 12). The estimated ETI with only variation from state rates is 0.34 for the 1980s. The estimated ETI is just 0.11 for the 1990 s and 0.23 for the full period. For broad income, the estimated elasticity is much larger for the 1980s when including only variation in state rates $(0.37$ versus 0.21 when both state and federal rates are included). For the 1990s, the estimated broad income elasticity $(0.08)$ is slightly smaller than the earlier estimate and much smaller than the estimate for the 1980s. For the full period, the estimated broad-income elasticity is about the same as when only variation in federal rates is included or when both state and federal rates are included.

\section{Permanent versus Transitory Responses}

While the model is designed to capture permanent rather than transitory responses, the degree to which is does this is open to question. Focusing on changes in behavior over three-year intervals is intended to isolate permanent responses. But that comparison may not remove transitory influences from the elasticity estimates. Many of the years in both the 1980s and1990s are likely to include some transitory behavior, in part because of multiyear phase-in periods. Thus, comparing observations three years apart is unlikely to avoid transitory fluctuations. If those transitory fluctuations severely contaminate measurement of the permanent responses, differences in ETI estimates for the two periods may result simply from noise. To test this possibility, the ETI is re-estimated after excluding all paired observations that include years 1981, 1982, 1986, 1987, 1993, 1994 and 2001. For the full time period, the overall estimated ETI is 0.30 (versus 0.34 when no years are dropped) and strongly significant. The corresponding estimated ETI is 0.36 for the 1980 s and 0.15 for the 1990s. The fact that the estimates are all a little smaller than the corresponding estimates that do not exclude any years suggests that the overall estimates may contain both a permanent plus a small transitory component. However, this is far from conclusive- especially since the 1980s estimate is no longer statistically significant (see Table 13).

\section{Why Might Estimates for the 1980s and 1990s Differ?}

Three competing interpretations might explain the differences between the results from the 1980s and the 1990s:

1. The model does a good job of explaining overall behavior for both the 1980s and the 1990s, but differences in policy and economic factors caused the ETI to fall between the two periods. That hypothesis is consistent with the view of Slemrod and Kopczuk (2002), who argue that the ETI is not a structural parameter 
TABLE 13

FULL SOI ESTIMATES AFTER EXCLUDING YEARS THAT ARE THE MOST LIKELY CONTAIN TRANSITORY BEHAVIOR

\begin{tabular}{lcc}
\hline & $\begin{array}{c}\text { Broad } \\
\text { Income }\end{array}$ & $\begin{array}{c}\text { Taxable } \\
\text { Income }\end{array}$ \\
\hline 1979 to 1987 & 0.102 & 0.356 \\
& $(0.113)$ & $(0.255)$ \\
Obs & 64,769 & 57,709 \\
1988 to 1998 & 0.076 & 0.149 \\
& $(0.048)$ & $(0.074)$ \\
Obs & 291,611 & 255,492 \\
1979 to 1998 & 0.183 & 0.299 \\
& $(0.040)$ & $(0.064)$ \\
Obs & 356,380 & 313,209 \\
\hline
\end{tabular}

Notes: Estimates are based on Statistics of Income data. Estimates are from 2SLS regressions and include a 10-Piece Spline of $\ln$ (Income). The income range is $\$ 10,000$ and above. Regressions are weighted by the inverse of sampling probabilities and by income (see the third section). Robust standard errors (clustered by individual) are in parentheses. Coefficients other than the elasticities are suppressed.

and is a function of more than preferences. If the different estimates are due solely to changes in the base, then an estimate for the 1990s (or any other period) can be imputed from Kopczuk's estimated coefficients and a measure of the tax base. ${ }^{34}$ Kopczuk's measure of the tax base, which is intended to proxy the cost of shifting income from inside to outside the tax base, has been relatively constant post-TRA 86. Inserting the tax base for the 1990s into his estimated equations suggests that the ETI should be two to four percentage points lower in the 1990s than it was pre-1986. That would explain 14 to 29 percent of the difference between my estimates for the 1980s and 1990s. Of couse, Kopczuk's measure is an imperfect proxy for the cost of shielding income from taxation. It is possible that a better measure would explain more of the difference (or possibly less). ${ }^{35}$

2. The model is misspecified and does a poor job of isolating the response of taxable income to tax rate changes in either period-even when employing separate controls for mean reversion and non-tax-related divergence in the income distribution. During the 1980s, for example, reported taxable incomes were rising, and the share of taxable income reported by the top of the income distribution was growing rapidly. At the same time, marginal tax rates were falling, with the largest reductions at the high end of the income distribution. Thus, the larger estimated ETIs for the 1980s might occur not because the true response was greater, but because the model fails to control fully for the correlation between non-tax-related growth in income (especially at the top of the distribution) and falling tax rates. In the 1990s, the correlation between tax rates and income was reversed: The trend in income at the high end continued, and marginal tax rates were increasing as a result of the Omnibus Budget Reconciliation Acts of 1990 and 1993. For the 1990s, the failure to control fully for that correlation biases estimated ETIs downward, the opposite of the upward bias for the 1980s. Lending credence to that interpretation is the fact that the rate cuts of the 1990s applied only to upper-income groups, which are usually more responsive to tax

${ }_{34}$ Kopczuk's measure of the tax base is the share of income subject to tax-i.e., taxable income (plus certain deductions and exclusions that are not affected by behavior) divided by total income. His model includes two separate explanatory variables that are functions of the marginal tax rate. One is the net-of-tax rate; the other is one minus the tax base (share) interacted with the net-of-tax rate.

35 Another interpretation in support of the model is that people simply respond differently to rate cuts than they do to rate increases. 
rates than are other groups. Thus, it is somewhat surprising that the estimated ETI is lower, rather than higher, for the 1990s.

3. The model and data may fail to capture some potentially important types of income shifting. For example, the shifting of income between the corporate and individual base is often not observed. Incentives for this type of shifting were more prevalent for the 1980s than for the 1990s. The mostly unobserved shifting of income from subchapter $C$ to subchapter $\mathrm{S}$ corporations following TRA 86 likely played a large role in biasing some of the early ETI estimates for TRA 86 (see Slemrod, 1996). Additionally, Saez (2004) attributes much of the income increase at the very top of the income distribution following ERTA 1981 to a surge in income from subchapter $S$ corporations. This income surge could have arisen from a number of sources, including: tax-induced changes in real economic activity; the shifting of income from subchapter $\mathrm{C}$ to subchapter S corporations; and an exogenous (non-tax-related) change in economic activity. The potential measurement problems created from income shifting between subchapter $\mathrm{C}$ and $\mathrm{S}$, as well as the possibility of not fully accounting for non-taxrelated changes in economic activity (that affect subchapter $\mathrm{S}$ income) are mitigated by excluding subchapter $\mathrm{S}$ income from the analysis. It is still possible that better accounting of income shifting between corporate and individual bases-shifting between subchapters $S$ and $C$ is just one piece of the puzzle-could help explain why the estimates for the two decades are different.

\section{Estimates for High-Income Filers from the Full SOI}

A number of studies have found that estimated ETIs vary greatly by income, and that overall responses may be driven by high-income filers. While comparing dollar-weighted and person-weighted estimates (which are generally much smaller) also suggests this, the possibility is explored further by using the full SOI to generate ETI estimates that apply specifically to high-income filers.

Table 14 presents income-weighted ETI estimates for the 1980s, 1990s, and for both decades combined after excluding those with less than $\$ 100,000$ of base-year broad income. With that income restriction, the 1980s and 1990s estimates are very similar to the full-sample SOI estimates for the respective periods. For both decades combined, though, the estimated ETI is 0.44 (versus 0.34 for the sample without the higher-income restriction), which is actually larger than either the 1980s or 1990s estimate. ${ }^{36}$ Note that restricting the sample to those with incomes over $\$ 100,000$ alters a potentially important source for identification. That is, the exclusion reduces degree of cross-sectional variation in tax

TABLE 14

FULL SOI DOLLAR-WEIGHTED TAXABLE-INCOME ELASTICITIES FOR UPPER-INCOME FILERS

\begin{tabular}{lc}
\hline Time-Period & ETI \\
1979 to 1998 & 0.441 \\
& $(0.089)$ \\
1979 to 1987 & 0.426 \\
& $(0.148)$ \\
1988 to 1998 & 0.232 \\
& $(0.098)$ \\
\hline
\end{tabular}

Notes: Estimates are based on Statistics of Income data for years 1979 to 2001. Estimates are based on the specification with a 10-piece spline. Regressions are weighted by the inverse of sampling probabilities and by income (see the third section). Robust standard errors (clustered by individual) are in parenthesis.

36 The estimate for the 1980 s (for those with income over $\$ 100,000$ ) is 0.43 . For comparison, Gruber and Saez, using the CWHS, reported an estimated ETI of 0.57 when making this same restriction to the sample. 
rate changes and, thus, the behavior of those with less than $\$ 100,000$ of income is no longer used to help explain counterfactual income trends. Whether this hampers or improves the identification process depends partly on whether the non-tax-related behavior of the excluded group is similar to that of the included higher-income group.

\section{CONCLUSION}

This paper builds on Gruber and Saez (2002). In addition to replicating Gruber and Saez's core results using CWHS data, a number of sensitivity analyses are conducted, including extending the data through the 1990s - so that the full period includes both tax increases and tax decreases. After finding evidence that the CWHS results may not be robust because of the small number of very-high-income filers, the analysis is repeated using the full SOI-a much larger dataset that includes the CWHS, but also heavily over-samples high-income filers.

One important finding is that when employing identical methodologies, estimated ETIs for the tax increases of the 1990s are generally much smaller (about half the size) than estimates for the tax cuts of the 1980s. A second finding is that although sample sizes are quite large, CWHS-based ETI estimates for the 1990s are not statistically significant. This is partly due to income-weighting the regressions, which places much greater emphasis on the responses of high-income filers and, thus, makes the size of the sample somewhat misleading. Additionally, despite the large sample size, a dfbeta test for the 1980s shows that results depend heavily on a few very-high-income observations. However, moving to the full SOI results in estimated ETIs that are generally similar in magnitude to the CWHS estimates, but with much smaller standard errors. This suggests that the CWHS, while inferior to the full SOI, may well be a use- ful data source for examining behavior often dominated by very-high-income filers. A third finding is that using separate control variables for mean reversion and divergence within the income distribution has a modest and negative effect on estimated ETIs for the 1980s and a positive and larger effect on estimates for the 1990s (when compared to results from analogous models that include just one variable to account for both phenomena).

The addition of high-income filers from the SOI, along with a panel that spans over 20 years and includes both tax increases and tax decreases, yields results that are more robust than many previous studies. This paper suggests a relatively narrow range of plausible estimates for the ETI. However, the factors that underlie income changes are tremendously complex and there remains variation across specifications and across time periods that is not well understood. Furthermore, other credible studies suggest a wider range of plausible estimates (see Giertz (2006) and Heim (2007)).

\section{Acknowledgments}

I wish to thank David Weiner, Ed Harris, Emmanuel Saez, Rob McClelland, Bob Williams, Wojciech Kopczuk and two anonymous referees for helpful comments and for assistance with the data construction.

\section{REFERENCES}

Auten, Gerald, and Robert Carroll.

"The Effect of Income Taxes on Household Behavior." Review of Economics and Statistics, 81 No. 4 (November, 1999): 681-93.

Bakija, Jon.

"Documentation for a Comprehensive Historical U.S. Federal and State Income Tax Calculator Program." Williams College. Mimeo, 2006. www.williams.edu/ Economics/papers/bakijaDocumentation _IncTaxCalc.pdf 
Feldstein, Martin.

"The Effect of Marginal Tax Rates on Taxable Income: A Panel Study of the 1986 Tax Reform Act." Journal of Political Economy 103 No. 3 (June, 1995): 551-72.

Feldstein, Martin.

"Tax Avoidance and the Deadweight Loss of the Income Tax." Review of Economics and Statistics 81 No. 4 (November, 1999): 674-80.

Feldstein, Martin, and Marian Wrobel. "Can State Taxes Redistribute Income?" Journal of Public Economics 68 No. 3 (September, 1998): 369-96.

Giertz, Seth.

"The Elasticity of Taxable Income During the 1990s: A Sensitivity Analysis." CBO Working Paper No. 2006-3. Washington D.C.: U.S. Congressional Budget Office, February, 2006. www.cbo.gov/ftpdocs/70xx/ doc7037/2006-03.pdf.

Giertz, Seth.

"Recent Literature on Taxable-Income Elasticities." CBO Technical Paper No. 2004-16. Washington D.C.: U.S. Congressional Budget Office, December, 2004. www.cbo. gov/ftpdocs/60xx/doc6028/2004-16.pdf.

Goolsbee, Austan.

"Evidence on the High-Income Laffer Curve from Six Decades of Tax Reforms." Brookings Papers on Economic Activity 1999 No. 2 (1999): $1-47$.

Gruber, Jonathan, and Emmanuel Saez.

"The Elasticity of Taxable Income: Evidence and Implications." Journal of Public Economics 84 No. 1 (April, 2002): 1-32.

Heim, Bradley.

"The Elasticity of Taxable Income: Evidence from a New Panel of Tax Returns." Mimeo, 2007.

Internal Revenue Service (IRS).

"Individual Income Tax Returns with Positive Adjusted Gross Income (AGI)." Unpublished Statistics of Income Data. Washington, D.C.: Internal Revenue Service, September, 2004.

Internal Revenue Service (IRS).

"Individual Income Tax Returns-Publication 1304." Statistics of Income. Washington,
D.C.: Internal Revenue Service, 1979 1998.

Harig, Bob.

"The $19^{\text {th }}$ Hole." St. Petersburg Times (October 14, 2004): C-8.

Imbens, Guido, and Tony Lancaster.

"Efficient Estimation and Stratified Sampling." Journal of Econometrics 74 No. 2 (October, 1996): 289-318.

Jones, Gregg.

"The Nation on State Tax Policy: Everyone Has a Formula for Reform." Los Angeles Times (February 25, 2003): A-1.

Kopczuk, Wojciech.

"Tax Bases, Tax Rates and the Elasticity of Reported Income." Journal of Public Economics 89 No. 11-12 (December, 2005): 2093-119.

Lemieux, Thomas.

"Post-secondary Education and Increasing Wage Inequality." American Economic Review Papers and Proceedings 96 No. 2 (May, 2006): $1-23$.

Piketty, Thomas, and Emmanuel Saez.

"Income Inequality in the United States, 1913-1998." Quarterly Journal of Economics 118 No. 1 (February, 2003): 1-39.

Piketty, Thomas, and Emmanuel Saez.

"How Progressive Is the U.S. Federal Tax System? A Historical and International Perspective." Journal of Economic Perspectives 21 No. 1 (Winter, 2007): 3-24.

Saez, Emmanuel.

"Reported Incomes and Marginal Tax Rates, 1960-2000: Evidence and Policy Implications." In Tax Policy and the Economy 18 edited by James Poterba, 117-73. Cambridge: The MIT Press, 2004.

Saez, Emmanuel, and Michael Veall.

"The Evolution of High Incomes in Northern America: Lessons from Canadian Evidence." American Economic Review 95 No. 3 (June, 2005): 831-49.

Slemrod, Joel.

"High Income Families and the Tax Changes of the 1980s: The Anatomy of Behavioral Response." In Empirical Foundations of Household Taxation, edited by Martin Feldstein and James Poterba, 169-89. 
Chicago: University of Chicago Press, 1996.

Slemrod, Joel.

"Methodological Issues in Measuring and Interpreting Taxable Income Elasticities." National Tax Journal 51 No. 4 (December, 1998): 773-88.
Slemrod, Joel, and Wojciech Kopczuk.

"The Optimal Elasticity of Taxable Income." Journal of Public Economics 84 No. 1 (April, 2002): 91-112. 